Atıf: Kılar, H., Çiçek, İ. (2019). Kıyı Çizgisinin Gelecekteki Konumunun Belirlenmesinin Önemi: Göksu Deltası Örneği, Mersin (Türkiye), Coğrafi Bilimler Dergisi/ Turkish Journal of Geographical Sciences, 17(1), 193-216, doi: 10.33688/ aucbd.559328

\begin{tabular}{ccc} 
Coğrafi Bilimler Dergisi & Courafi \\
Bilimler & Dergisi \\
\hline & Turkish Journal of Geographical Sciences & e-ISSN:1308-9765 \\
\hline
\end{tabular}

\title{
Kıyı Çizgisinin Gelecekteki Konumunun Belirlenmesinin Önemi: Göksu Deltası Örneği, Mersin (Türkiye)
}

\section{The importance of determining the future position of shoreline: The case study of Göksu Delta, Mersin (Turkey)}

Hatice Kılara*, İhsan Çiçek ${ }^{b}$

\begin{tabular}{l} 
Makale Bilgisi \\
\hline DOI: \\
10.33688/ aucbd.559328 \\
\hline Makale Geçmişi: \\
Geliş: 28.09.2018 \\
Kabul: 13.03.2019 \\
\hline Anahtar Kelimeler: \\
Kiyı Çizgisi \\
Gelecek Tahmini \\
DSAS \\
Göksu Deltas1 \\
\end{tabular}

\begin{tabular}{l} 
Article Info \\
\hline DOI: \\
10.33688/ aucbd.559328 \\
\hline Article History: \\
Received: 28.09 .2018 \\
Accepted: 13.03 .2019 \\
\hline Keywords: \\
Shoreline Change \\
Future Prediction \\
DSAS \\
Göksu Delta
\end{tabular}

$\ddot{O} z$

Kıyı çizgisi değişimlerinin belirlenmesi, kıyı alanları ile ilgili bilimsel, politik ve yasal kararların alınmast ve bunların verimli bir şekilde uygulanmass açısından son derece önemlidir. Bu çalışmada, Göksu deltasının geçmiş yıllara ait klyı çizgisi değişim değgerlerinden yola çıkılarak klyı çizgisinin gelecekteki konumunun modellenmesi amaçlanmıştır. Bu amaç doğrultusunda, Göksu deltasının 1984-2017 yılları arasındaki kıyı çizgisi değişim değerleri DSAS aracının (Sayısal Kıyı Analizi) NSM istatistiği (Kesin Kıyı Çizgisi) ile değerlendirilmiş ve çalışma sahasının 25 ve 50 yıl sonraki kıyı çizgisi konumları hesaplanmıştır. Çalışmanın sonucunda, Göksu deltasında aşınmanın hâkim olduğu alanlarda 25 yıl sonra kıyı çizgisinde ortalama 114 $m$ gerileme meydana geleceği; birikme alanlarında ise klyı çizgisinin ortalama 119 m ilerleyeceğ $i$ hesaplanmıştır. Bunun yanı sıra, çalışma sahasında 50 yıl sonra aşınmanın hâkim olduğu alanlarda kıyı çizgisi gerilemesinin ortalama $223 \mathrm{~m}$ olmasi beklenirken; birikme faaliyetlerinin hâkim olduğu alanlarda klyı çizgisi ilerlemesinin ortalama 236 m olacă̆ tespit edilmiştir.
Abstract
Defining the coastline changes in coastal zones is extremely important in terms of taking and implementing scientific, political and legal decisions. In this study, modelling of the future shoreline position of Göksu delta was aimed. For this purpose, the shoreline change values of the Göksu Delta belong to 1984-2017 years was evaluated by using Net Shoreline Movement (NSM) statistic of Digital Shoreline Analysis Tool (DSAS). Then, the future shoreline position of Göksu Delta 25 and 50 years later were calculated. In conclusion, it was ascertained that there will be $114 \mathrm{~m}$ rate of shoreline regression in erosion dominated areas while the rate of shoreline progress in accumulation dominated areas will be $119 \mathrm{~m} 25$ years later. On the other hand, the rate of shoreline regression in erosion dominated areas will be 223 $m$ whereas there will be $236 m$ rate of shoreline progress in accumulation dominated areas 50 years later.

\footnotetext{
*Sorumlu Yazar/Corresponding Author: kilar_hatice@ @otmail.com

${ }^{a}$ Ankara Üniversitesi, Coğrafya Bölümü, Ankara, Türkiye, https://orcid.org/0000-0002-2423-4712

bAnkara Üniversitesi, Coğrafya Bölümü, Ankara, Türkiye, https://orcid.org/0000-0002-9000-2805
} 


\section{Giris}

Kıyı çizgisinin gelecekteki pozisyonunun belirlenmesi kıyı alanları ile ilgili uzun dönemli planlamaların gerçekleştirilmesi ve kıyı yönetimi ile ilgili etkili kararların alınmasında büyük önem taşımaktadır (Davidson, vd., 2010: 620; Fenstret, vd., 1993: 147). Kıyı çizgisinin gelecekteki pozisyonu belirlenirken kompleks morfolojik etkiler dikkate alınmadan geçmiş yıllara ait aşınma ve birikme oranlarının yıllık ortalamasının doğrusal bir eğilime dönüştürülmesi ile gerçekleştirilmektedir (Davidson, vd., 2010: 620). Bu nedenle, geçmiş yıllara ait kıyı çizgisi değişim değerlerinin belirlenmesi kıyı çizgisinin gelecekteki pozisyonunun belirlenmesinde büyük önem taşımaktadır (Fenstret, vd., 1993: 147).

Günümüzde, geçmiş yıllara ait kıyı çizgisi değişim değerlerinin belirlenmesi ile ilgili literatürde oldukça fazla çalışma bulunmasına karşın; kıyı çizgisinin gelecekteki pozisyonunun belirlenmesi ile ilgili sınırlı sayıda çalışma bulunmaktadır. Bu çalışmalardan bir kısmı kıyı çizgilerinin gelecekteki konumlarının belirlenmesi ile ilgili farklı yöntemlerin geliştirilmesine yönelik iken (Crowel, vd., 1997: 1246; Fenstert, vd. 1993: 149); bir kısmı da kıyı çizgisinin gelecekteki pozisyonun tahmin edilmesine yöneliktir (Davidson, vd., 2010: 623; Douglas, vd., 1998: 1027; Douglas ve Crowel, 2000: 146).

Delta kıyıları genel olarak yükselti ve eğimi düşük, ekolojik açıdan kırılgan alanlardır (Kılar ve Çiçek, 2017: 3270; Kılar ve Çiçek, 2018: 92). Bu nedenle, delta kıyılarının kıyı çizgilerinin gelecekteki pozisyonlarının belirlenmesi delta kıyıları ile ilgili uzun dönemli planlama çalışmalarının hazırlanması ve etkili kararların alınmasına olanak sağlayarak delta kıyılarının sürdürülebilirliğine katkı sağlamaktadır. Göksu deltası kıyıları Akdeniz kıyıları içerisinde kıyı çizgisi değişimlerinin en hızlı gerçekleştiği alanlar arasında yer almaktadır (Gürbüz, 1994: 412; Karakoç ve Karabulut, 2010: 197; Kılar ve Çiçek, 2018: 102; Kuleli vd., 2011: 1145). Delta kıyılarında meydana gelen hızlı kıyı çizgisi değişimleri çalışma sahasının kıyı çizgisinin gelecekteki pozisyonun belirlenerek uzun dönemli planlama çalışmalarının hazırlanmasını gerekli kılmaktadır. Bu nedenle, çalışmada Göksu deltası kıyı çizgisinin 25 ve 50 yıl sonraki kıyı çizgisi pozisyonu belirlenerek çalışma sahası kıyılarının sürdürülebilirliğine katkı sağlanmak istenmiştir.

\section{2. Çalışma Alanının Genel Özellikleri}

Göksu deltas1, $36^{\circ} 15^{\prime}$ ve $36^{\circ} 25^{\prime}$ kuzey enlemleri ile $33^{\circ} 55^{\prime}$ ve $34^{\circ} 05^{\prime}$ doğu boylamları arasında Mersin ili sınırları içerisinde yer almaktadır. Göksu Nehri tarafından taşınan kil, silt, kum, çakıl boyutundaki sedimanların birikmesi sonucu oluşan Göksu deltas1 15.000 ha genişliğindedir. Deltanın yükseltisi ise 0-5 m arasında değişmektedir.

Göksu deltası, yazların sıcak ve kurak, kışların ise 1lık ve yağışlı geçtiği Akdeniz iklimi kuşağı etkisi altında yer almaktadır. Göksu deltası Silifke Meteoroloji İstasyonun 1970-2013 yıllarına ait sıcaklık ve yağış değerlerinin incelenmesi sonucunda sıcaklığın ortalama $19^{\circ} \mathrm{C}$ olduğu, yağışın ise ortalama $559 \mathrm{~mm}$ olduğu tespit edilmiştir.

Göksu deltası, su kaynakları açısından oldukça zengin bir topografyaya sahiptir. Deltadaki en önemli su kaynağı 260 km uzunluğunda ve 10.400 km²lik havza alanına sahip Göksu Nehri'dir. Bunun yanı sıra, Göksu deltası sınırları içerisinde 1.200 ha alana sahip Akgöl Lagünü ile 400 ha alana sahip Paradeniz Lagünleri bulunmaktadır. Deltadaki daha küçük göller ise Kuğu gölü, Arap alanı gölüdür. 
Göksu deltası, taban kenarı ana karaya bağlı çokgen geometrisi şekline sahiptir. Delta gerisinde, Devoniyen, Kretase, Oligosen ve Miyosen yaşlı kırıntılı ve karbonatlardan oluşan temel kayalar yüzeylenmektedir (Gedik vd., 1979: 7; Gökten, 1976: 117). Temel kayalar üzerinde ise geniş Pliyosen aşınım ve sıyrılma yüzeyleri yer almaktadır. Kuvaterner döneminden önceki morfolojik üniteler üzerinde flüviyal yarılmalar ve yamaç gelişimi gözlenmektedir (Keçer, 2001).

Göksu deltası ekolojik açıdan oldukça zengin bir ekosisteme sahiptir. Türkiye'deki kuş türlerinin 3/4 Göksu deltasında yaşaması, delta sınırları içerisinde 8'i endemik, 32'si nadir toplam 441 bitki türü bulunması delta kıyılarının özel statülerle korunma altına alınmasını gerekli kılmıştır (Gülkal, 1992; Karakoç ve Karabulut, 2010: 196; Keçer ve Duman, 2007: 17; Uslu, 1993). Göksu deltası 1989 yılında Yaban Hayatı Koruma Sahası (YHKS), 1991 yılında Özel Çevre Koruma Bölgesi (ÖÇKB), 1994 yılında Ramsar Alanı, 1996 yılında ise I. Derecede Doğal Sit ilan edilmiştir. Ayrıca, çeşitli uluslararası projeler kapsamında Göksu deltası Önemli Bitki Alanı (ÖBA), Önemli Doğa Alanı (ÖDA) ve Önemli Kuş Alanı (ÖKA) olarak da tanımlanmıştır (Karakoç ve Karabulut, 2010: 196; Meriç ve Kavruk, 2007: 198).
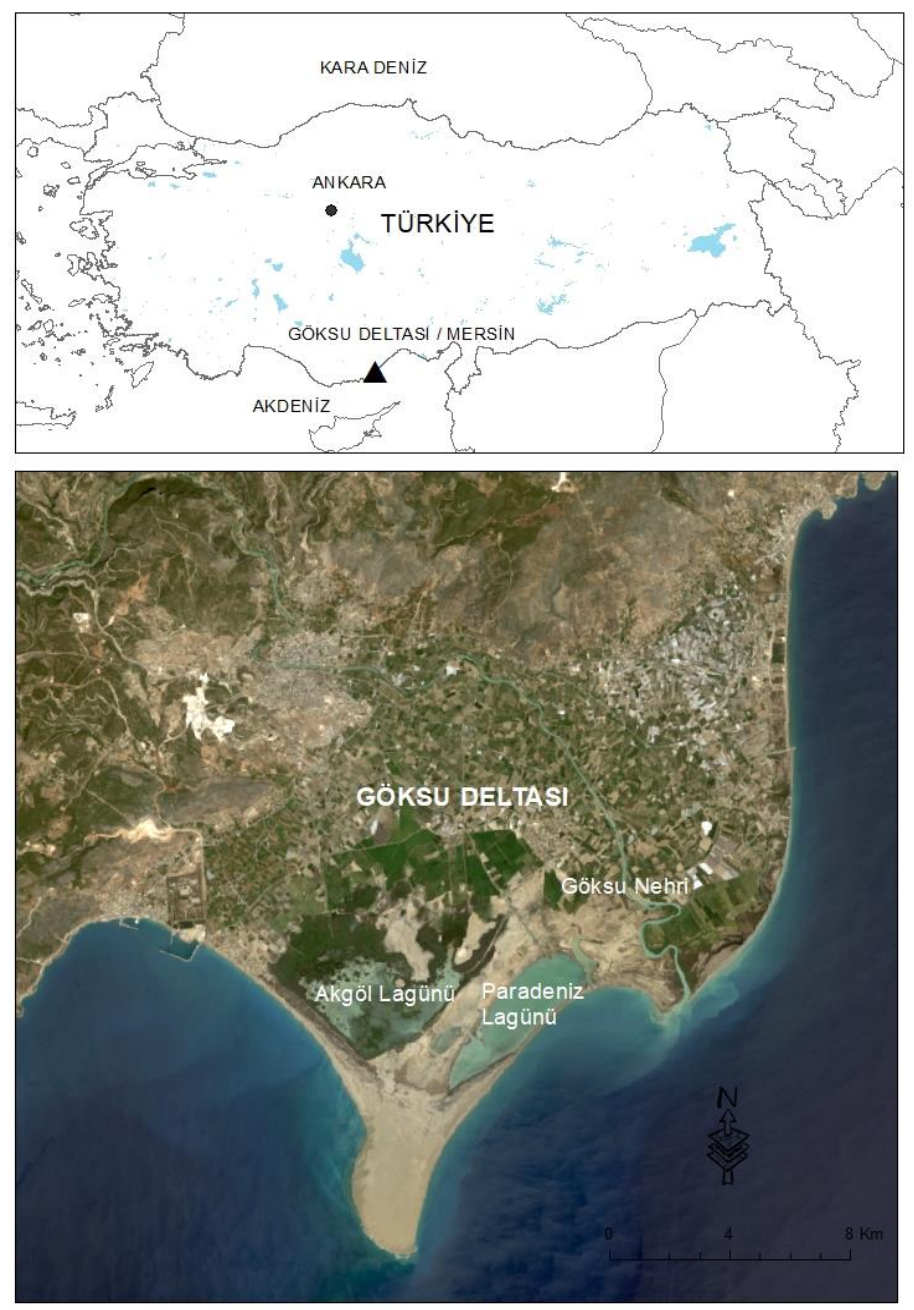

Şekil 1: Göksu Deltasının Konumu 


\section{Materyal ve Yöntem}

\section{1. Çalışmanın Gerçekleştirilme Aşaması}

Göksu deltası kıyı çizgisinin gelecekteki konumunun belirlenmesini amaçlayan çalışmada öncelikle çalışma sahasına ait veri setleri temin edilmiştir. Çalışmada, 02 Temmuz 1984 ve 11 Ağustos 2017 tarihlerine ait Göksu deltasının Landsat uydu görüntülerinden faydalanılmıştır (Çizelge 1). Çalışma sahasının geçmiş yıllara ait Landsat uydu görüntüleri öncelikle ENVİ programının "band orantılama" tekniğine tabi tutulmuş ve Göksu deltasının kıyı çizgisi haritaları üretilmiştir. Çalışmanın bir sonraki aşamasında Göksu deltasının 1984 ve 2017 yıllarına ait kıyı çizgisi haritaları DSAS aracının veri tabanına uygun olarak düzenlenmiş ve NSM istatistiğine göre değerlendirilerek çalışma sahasının kıyı çizgisi ilerleme ve gerileme değerleri metre olarak hesaplanmıştır. Çalışma sahasının geçmiş yıllara ait kıyı çizgisi değişim değerlerinin hesaplanmasında Landsat uydu görüntüleri için uygun görülen $\pm 5 \mathrm{~m}$ hata payı kriter olarak belirlenmiştir (Güneroğlu, 2015: 227; Kuleli, 2010: 393). Çalışmanın sonucunda, NSM istatistiğinden elde edilen Göksu deltasının geçmiş yıllara ait kıyı çizgisi değişim değerlerinden yola çıkarak çalışma sahasının 25 ve 50 yıl sonraki konumları belirleniştir (Şekil 2).

DSAS aracı, kısa ve uzun dönem kıyı çizgisi değişimlerinin farklı istatistiksel yöntemler ile değerlendirilmesi amacı ile geliştirilmiş ve ArcGIS programının eklentisi olarak çalışan bir yazılımdır (Thieler vd., 2009: 4). DSAS aracı bünyesinde yer alan istatistiklerden bazıları: Kesin Kıyı Çizgisi Hareketi/Net Shoreline Movement (NSM), Son Nokta Oranı/End Point Rate (EPR), Doğrusal Regresyon Oranı/Linear Regression Rate (LRR), Ağılıklı Doğrusal Regresyon/Weighted Linear Regression (WLR), Son Nokta Güven Oranı/Confidence of End Point Rate (ECI), Tahmini Hata Oran1/Standard Error of the Estimate (LSE and WSE) ve R-kare/R-squared (LR2 and WR2) istatistikleridir (Kılar ve Çiçek, 2018: 95; Thieler vd., 2009: 44).

Çizelge 1: Çalışmada Kullanılan Landsat Görüntülerinin Özellikleri

\begin{tabular}{llccc}
\hline Numara & Uydu Görüntüleri & Yol/Sıra & Tarih & Çözünürlük (m) \\
\hline 1 & Landsat MSS & $176 / 35$ & $02 / 07 / 1984$ & $60 x 60$ \\
2 & Landsat OLI TIRS & $176 / 35$ & $11 / 08 / 2017$ & $30 x 30$ \\
\hline
\end{tabular}




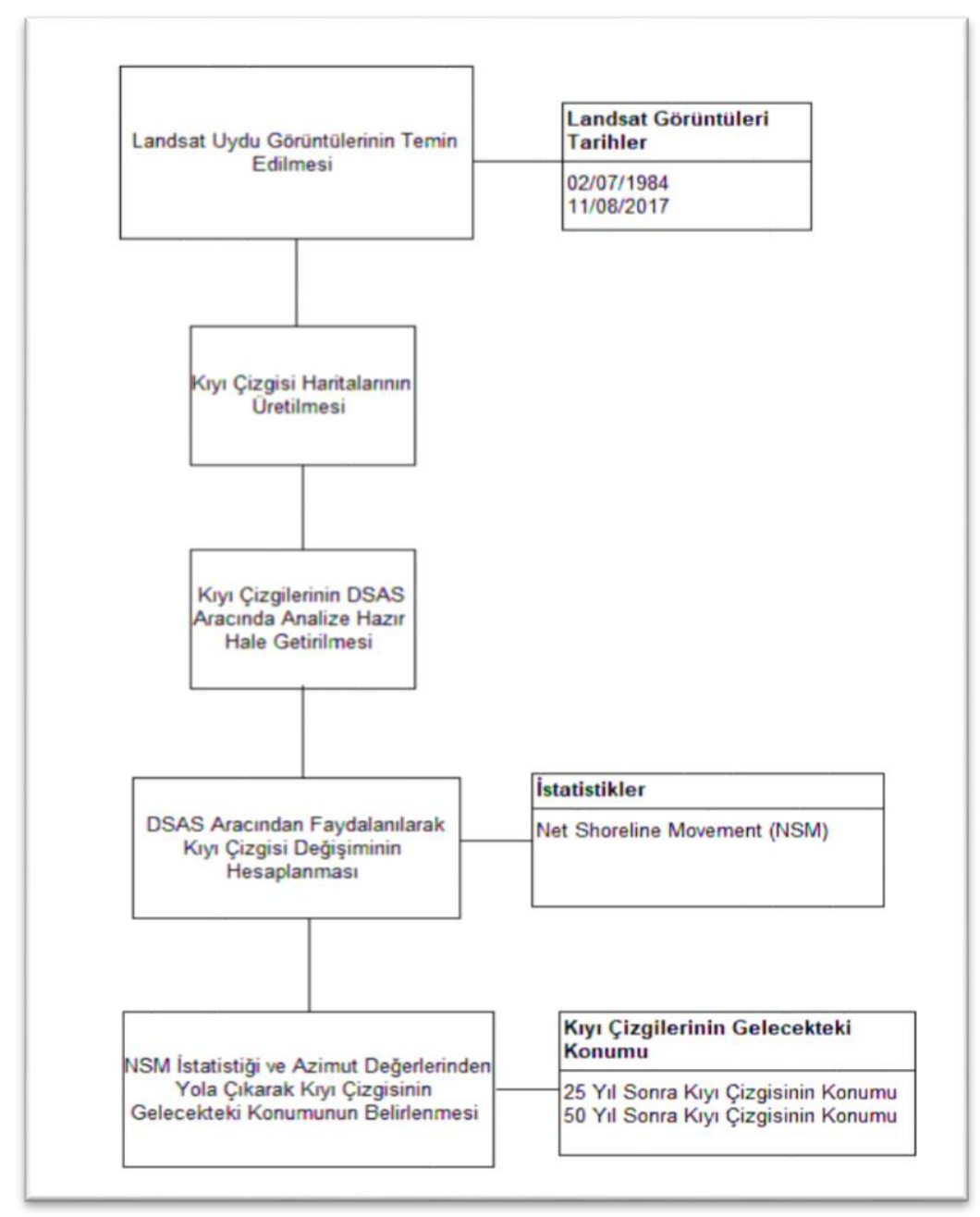

Şekil 2: Çalışma Akış Diyagramı

\section{Bulgular}

\subsection{Göksu Deltasının Uzun Dönemli Kıyı Çizgisi Değişimi}

\subsubsection{4-2017 Yılı NSM İstatistiği Kıyı Çizgisi Değişim Sonuçları}

Göksu deltasının 1984-2017 yılları arasındaki kıyı çizgisi değişiminin NSM istatistiğine göre değerlendirilmesi sonucunda en fazla kıyı çizgisi gerilemesinin 755 ve 396 m değerleri arasında Altınkum mevkii ile İncekum Burnu'nun güneybatı kıyılarında gerçekleştiği; en fazla kıyı çizgisi ilerlemesinin ise 277 ve $695 \mathrm{~m}$ değerleri arasında İncekum Burnu'nun batı kıyıları ile akarsu ağzı ve çevresinde meydana geldiği tespit edilmiştir (Şekil 3). Göksu deltası kıyı çizgisi değişimi NSM istatistiği grafiğinin değerlendirilmesi sonucunda ise en yüksek kıyı çizgisi ilerlemesinin 69-89 profil hatları boyunca ortalama $240 \mathrm{~m}$ ile İncekum Burnu'nun batı kıyılarında meydana geldiği; en yüksek kıyı çizgisi gerilemesinin ise 94 ve 118 profil hatları boyunca $386 \mathrm{~m}$ ile İncekum Burnu güneybatı kıyılarında meydana geldiği tespit edilmiştir (Şekil 4) (Kılar ve Çiçek, 2018: 98). 


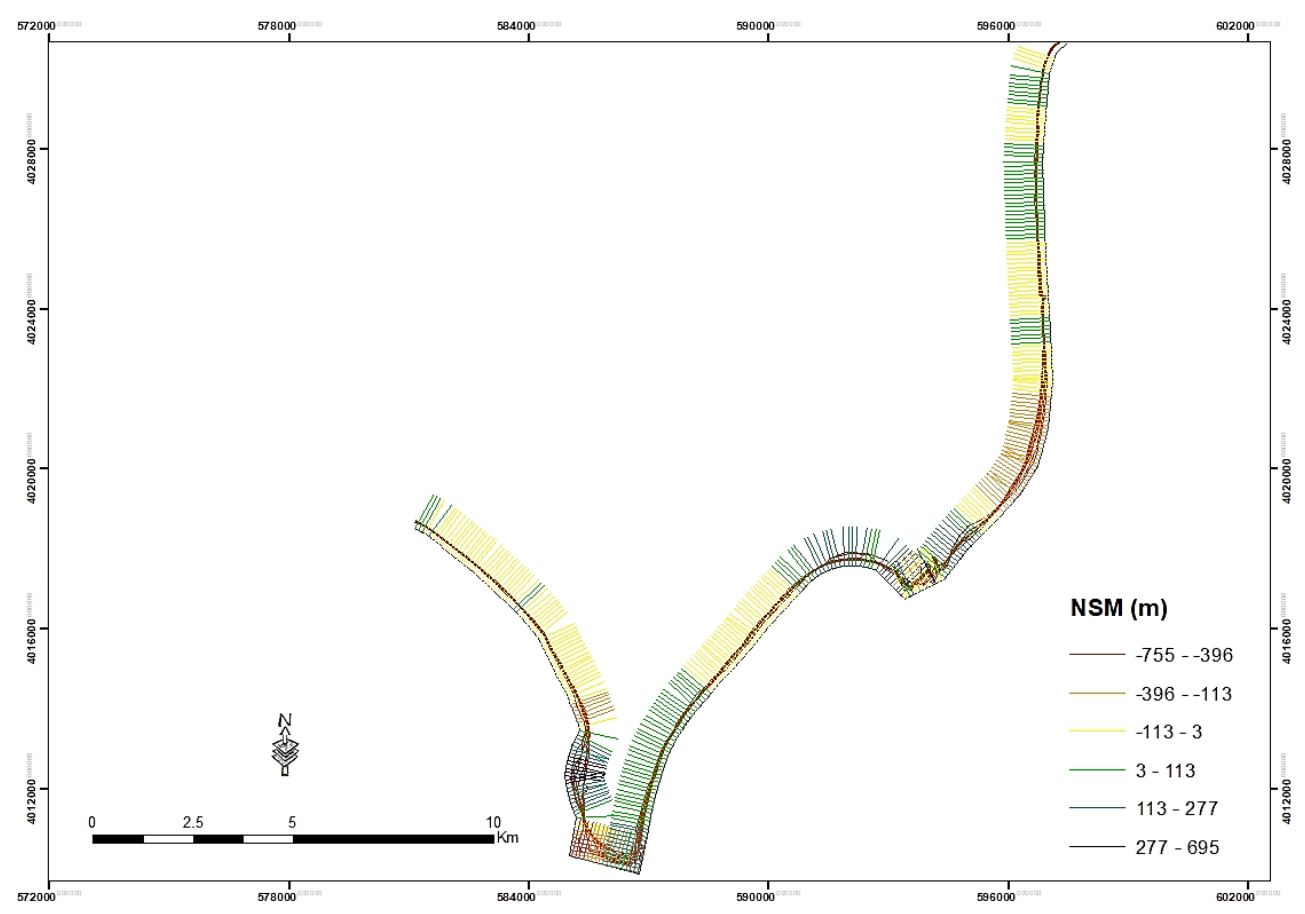

Şekil 3: 1984-2017 Yılı NSM İstatistiği Kıyı Çizgisi Değiş̧imi

Kaynak: Kılar ve Çiçek, 2018: 98

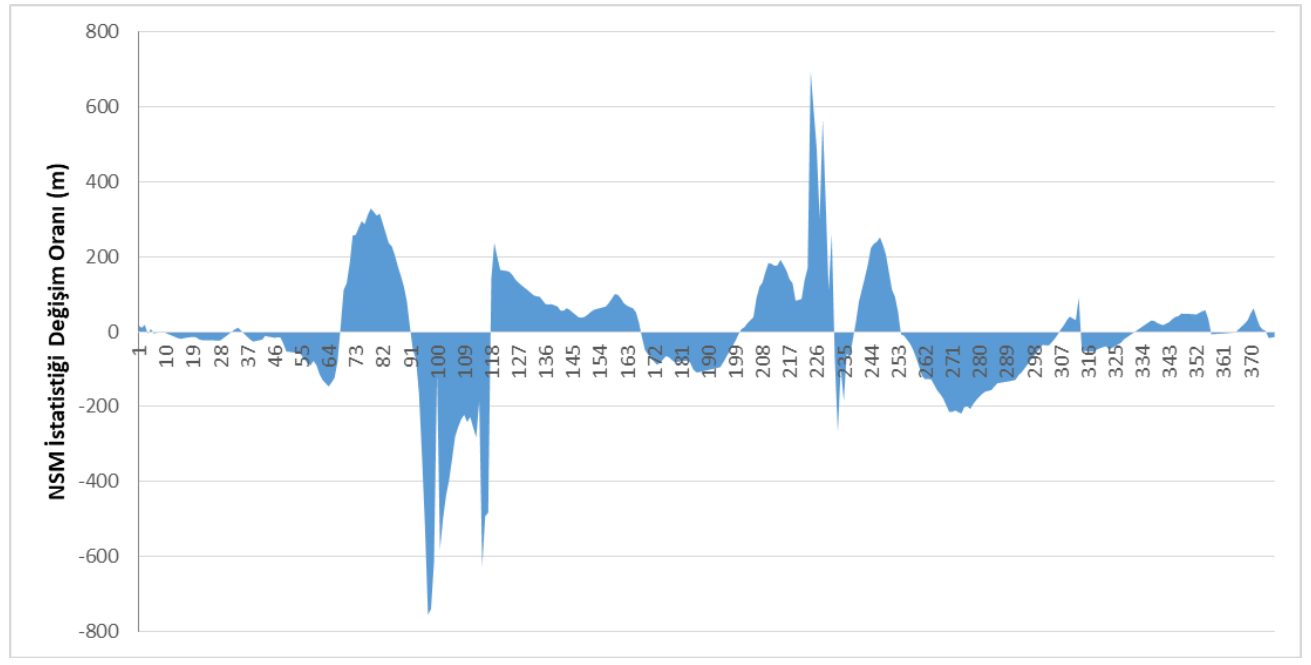

Şekil 4: 1984-2017 Yılı NSM İstatistiği Grafiği

Kaynak: Kılar ve Çiçek, 2018: 99

\subsubsection{Göksu Deltasının 25 Sonraki Kıyı Çizgisinin Konumu}

Göksu deltasının 25 yıl sonraki kıyı çizgisinin konumunun belirlenmesi için 193 profil hattı üretilmiştir. Profil hatlarının 100 tanesi çalışma sahasının aşınma bölgesinde yer alırken; 93 tanesi birikme bölgesinde yer almıştır. Göksu deltasının 25 yıl sonraki kıyı çizgisinin konumunun değerlendirilmesi sonucunda aşınma bölgelerindeki kıyı çizgisi gerilemesinin ortalama $114 \mathrm{~m}$; birikme bölgelerindeki kıyı çizgisi ilerlemesinin ise ortalama 119 m olacağı tespit edilmiştir (Şekil 5). 


\subsubsection{Aşııma Alanlarındaki Kıyı Çizgisinin 25 Yıl Sonraki Konumu}

Göksu deltasının aşınma alanlarındaki kıyı çizgisinin 25 yıl sonraki konumunun değerlendirilesi sonucunda en fazla kıyı çizgisi gerilemelerinin İncekum burnu batı kıyıları (a), İncekum burnu güneybatı kıyıları (b), Paradeniz lagünü kıyı kordonu (c) ve Altınkum mevkii’nde (d) gerçekleşeceği tespit edilmiştir (Şekil 6). Bunun yanı sıra, çalışma sahasının (a) bölgesinde 25 yıl sonraki kıyı çizgisi gerilemesi ortalama $68 \mathrm{~m}$ iken; (b) bölgesinde ortalama $218 \mathrm{~m}$; (c) bölgesinde ortalama $24 \mathrm{~m}$ ve (d) bölgesinde ortalama $106 \mathrm{~m}$ olacağı tespit edilmiştir. Bu durum, 25 yıl sonra Göksu deltasında en fazla kıyı çizgisi gerilemesinin İncekum burnunun güneybatı kıyılarında (a) meydana geleceğini göstermektedir (Şekil 6).

\subsubsection{Birikme Alanlarındaki Kıyı Çizisinin 25 Yıl Sonraki Konumu}

Göksu deltasının birikme alanlarındaki kıyı çizgisinin 25 yıl sonraki konumunun değerlendirilmesi sonucunda en fazla kıyı çizgisi ilerlemelerinin İncekum burnu batı kıyıları (a), İncekum burnu doğu kıyıları (b), Nehir ağzı mevkii'nin batı kıyıları (c) ve Nehir ağzı mevkii'nin doğu kıyılarında (d) gerçekleşeceği tespit edilmiştir. Bunun yanı sıra, çalışma sahasının (a) bölgesinde 25 yıl sonraki kıyı çizgisi ilerlemesi ortalama 177 m, (b) bölgesinde ortalama 57 m, (c) bölgesinde ortalama 105 m, (d) bölgesinde ortalama 137 m olacağı tespit edilmiştir. Bu durum, 25 yıl sonra Göksu deltasında en fazla kıyı çizgisi ilerlemesinin İncekum burnu batı kıyılarında (a) meydana geleceğini göstermektedir (Şekil 7).

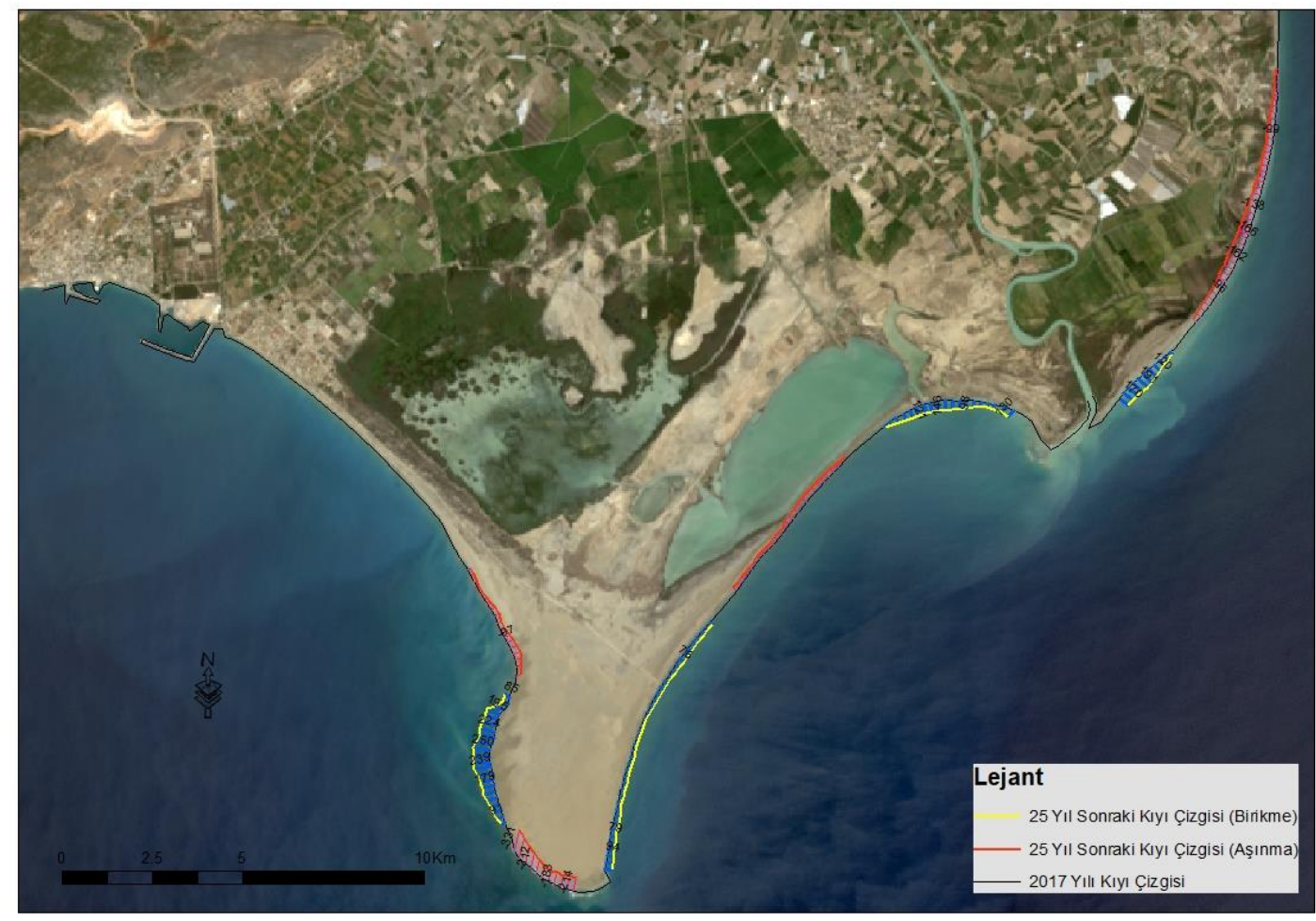

Şekil 5: Göksu Deltası 25 Yıl Sonra Aşınma Ve Birikme Sonucu Kıyı Çizgisi Değişimi 

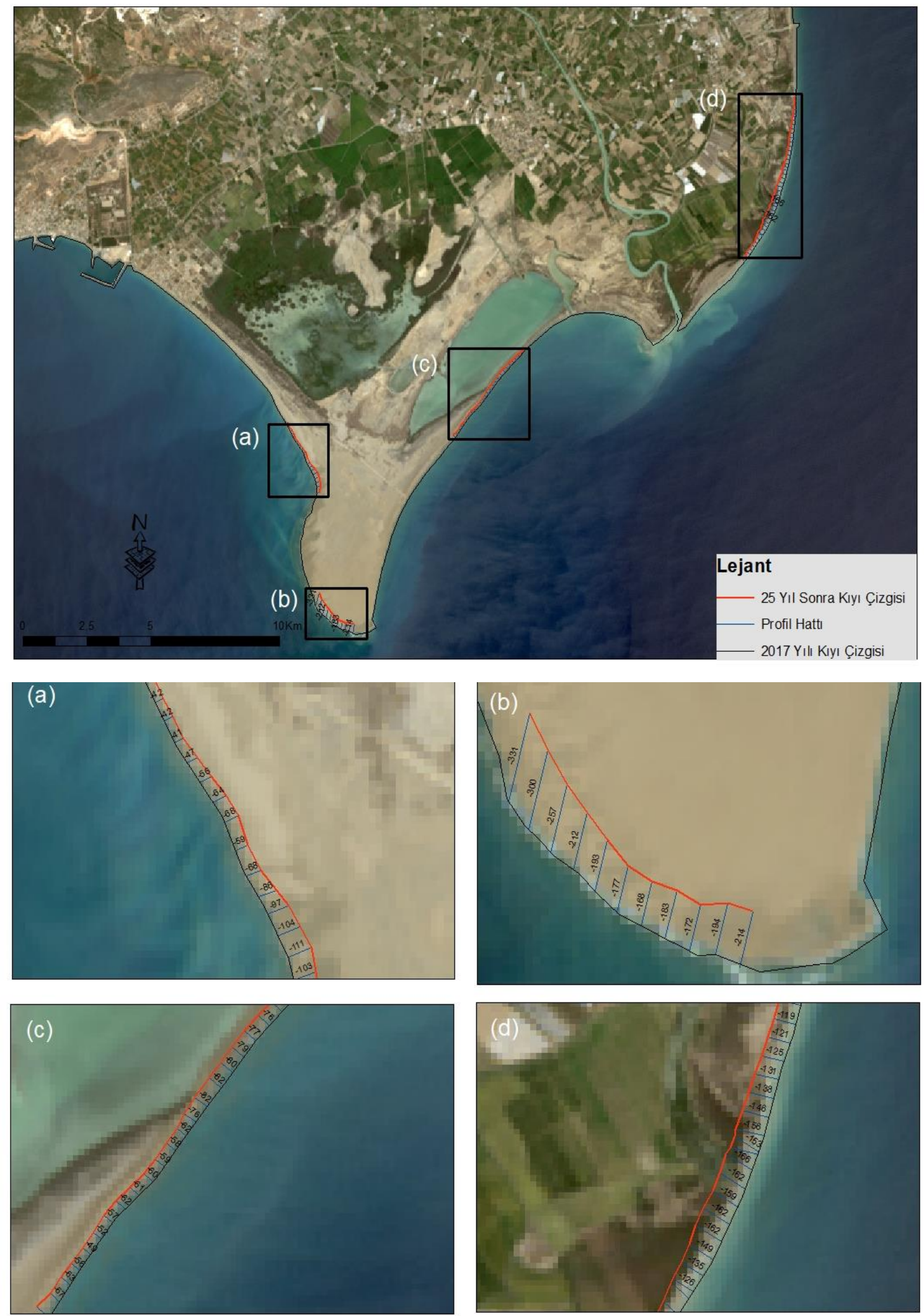

Şekil 6: Göksu Deltası Aşınma Alanlarındaki Kıyı Çizgisi Değişiminin 25 Yı1 Sonraki Konumu 

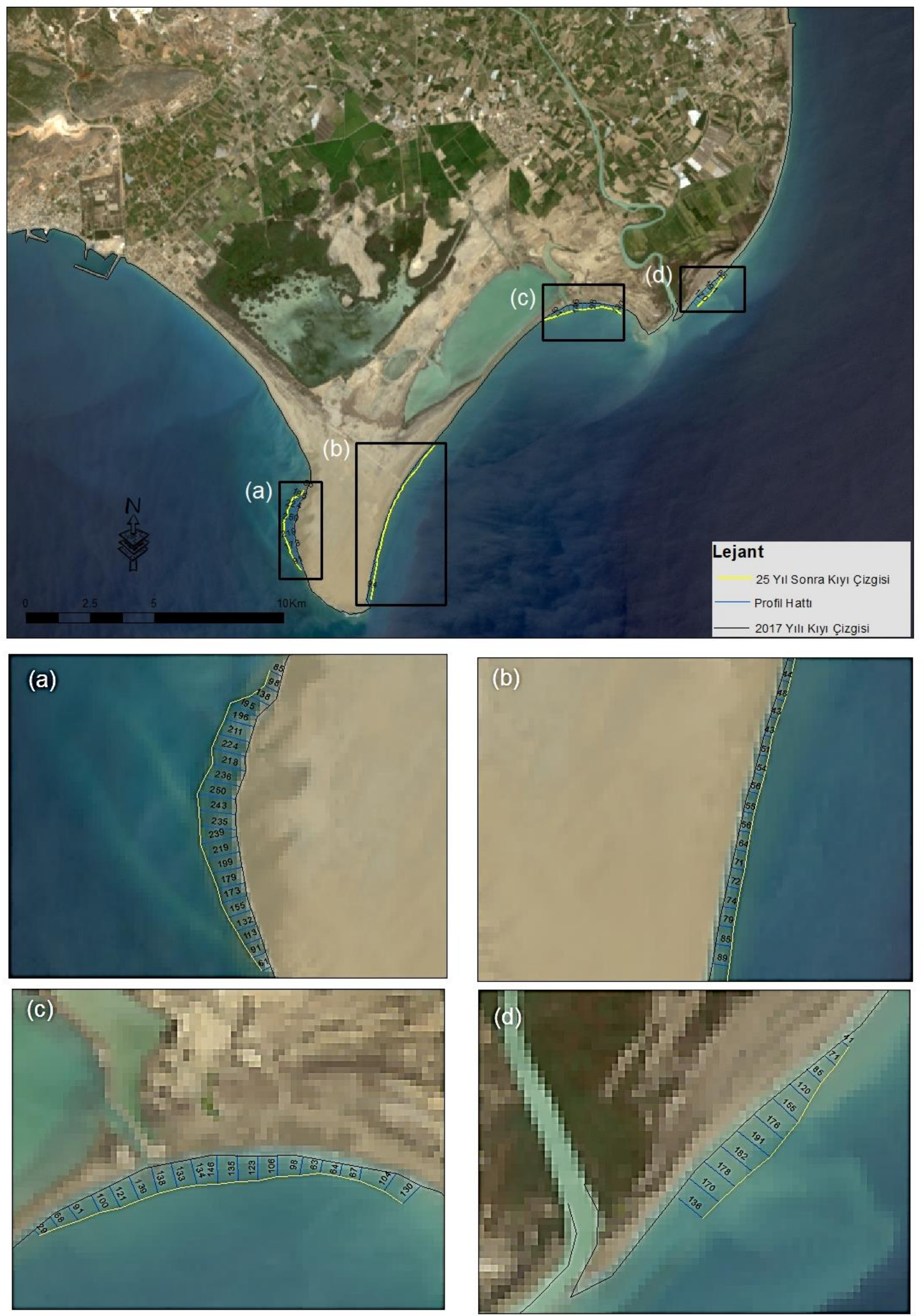

Şekil 7: Göksu Deltası Birikme Alanlarındaki Kıyı Çizgisi Değişiminin 25 Yı1 Sonraki Konumu 


\subsubsection{Göksu Deltasının 50 Sonraki Kıyı Çizgisinin Konumu}

Göksu deltasının 50 yıl sonraki kıyı çizgisinin konumunun belirlenmesi için 202 profil hattı üretilmiştir. Profil hatlarının 104 tanesi Göksu deltasının aşınma bölgesinde yer alırken, 98 tanesi birikme bölgesinde yer almıştır. Göksu deltasının 50 yıl sonraki kıyı çizgisinin konumunun değerlendirilmesi sonucunda aşınma bölgelerinde kıyı çizgisi gerilemesinin ortalama $223 \mathrm{~m}$, birikme bölgelerinde kıyı çizgisi ilerlemesinin ortalama 236 m olacağı tespit edilmiştir (Şekil 8).

\subsubsection{Aşınma Alanlarındaki Kıyı Çizgisinin 50 Yıl Sonraki Konumu}

Göksu deltasının aşınma alanlarındaki kıyı çizgisinin 50 yıl sonraki konumunun değerlendirilmesi sonucunda en fazla kıyı çizgisi gerilemelerinin (a) bölgesinde ortalama $131 \mathrm{~m}$, (b) bölgesinde ortalama 437 m, (c) bölgesinde ortalama 124 m, (d) bölgesinde ortalama 201 m olduğu tespit edilmiştir. Bu durum, 50 yıl sonra Göksu deltasında en fazla kıyı çizgisi gerilemesinin İncekum burnunun güneybatı kıyılarında (a) meydana geleceğini göstermektedir (Şekil 9).

\subsubsection{Birikme Alanlarındaki Kıyı Çizgisinin 50 Yıl Sonraki Konumu}

Göksu deltasının birikme alanlarındaki kıyı çizgisinin 50 yıl sonraki konumunun değerlendirilmesi sonucunda en fazla kıyı çizgisi ilerlemelerinin (a) bölgesinde ortalama $339 \mathrm{~m}$, (b) bölgesinde ortalama $121 \mathrm{~m}$, (c) bölgesinde ortalama $210 \mathrm{~m}$, (d) bölgesinde ortalama 274 m olacağ tespit edilmiştir. Bu durum, 50 yıl sonra Göksu deltasında en fazla kıyı çizgisi gerilemesinin İncekum burnu batı kıyılarında (a) meydana geleceğini göstermektedir (Şekil 10).

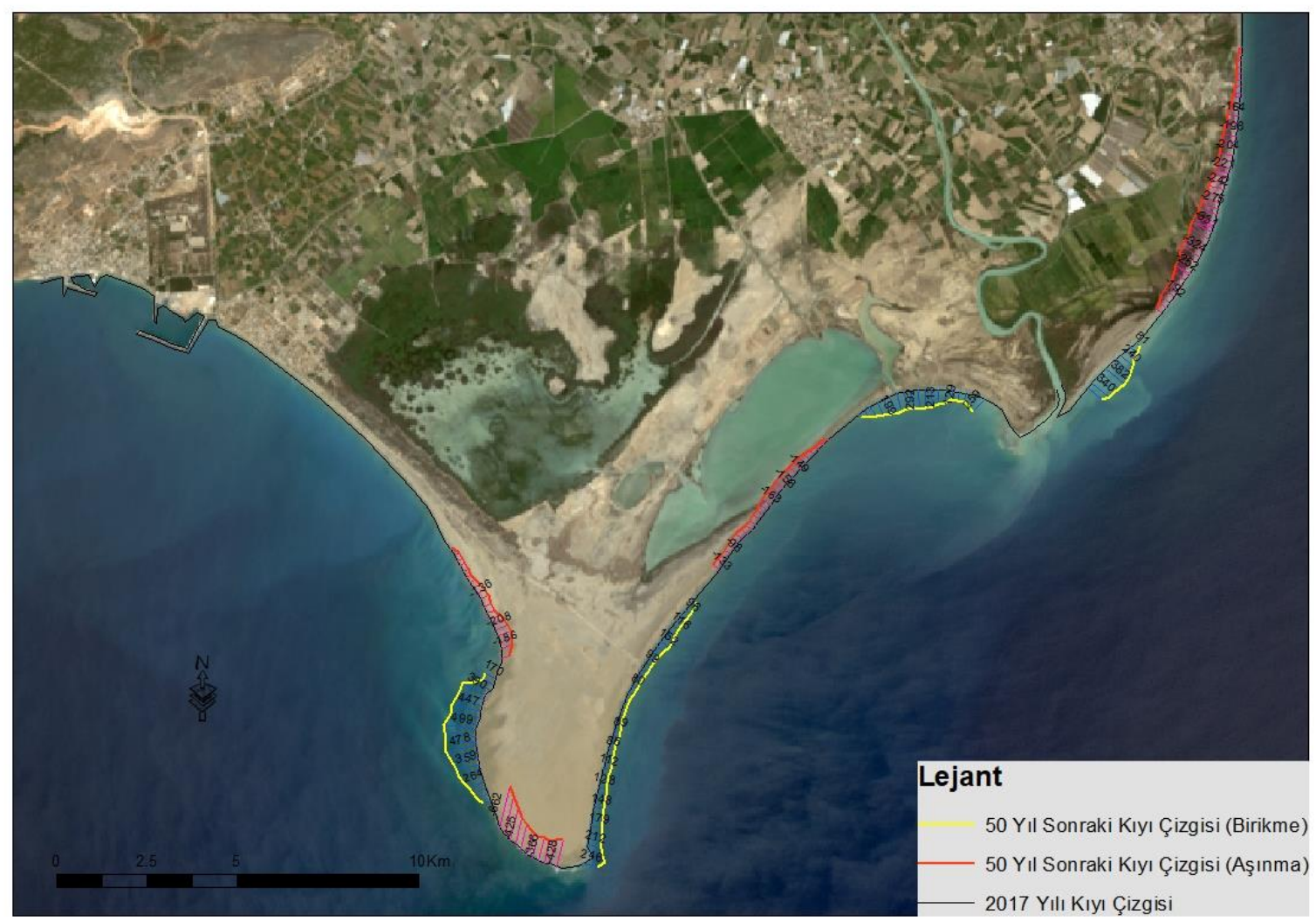

Şekil 8: Göksu Deltası Aşınma ve Birikme Sonucunda 50 Yı1 Sonra Kıyı Çizgisi Değişimi 

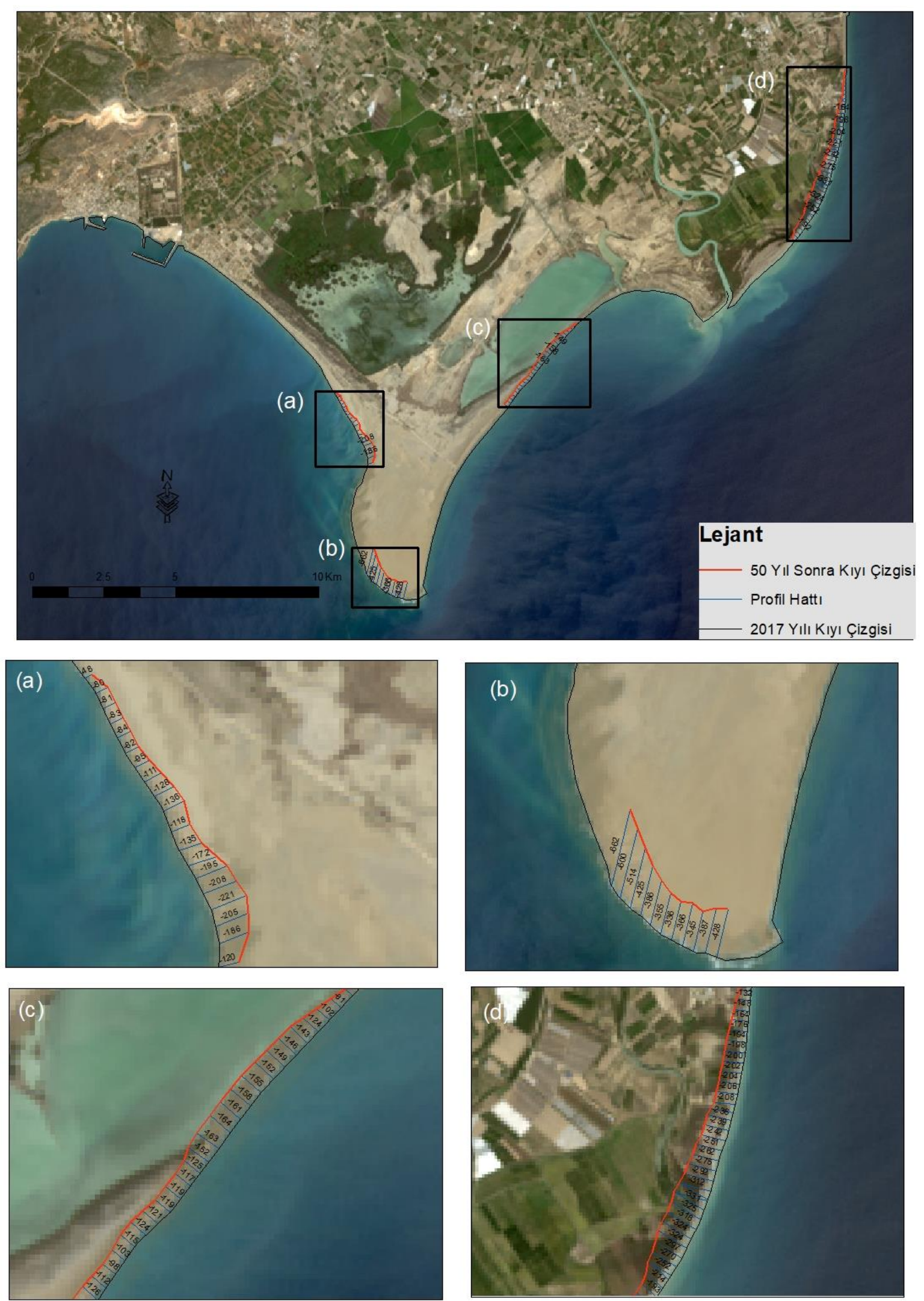

Şekil 9: Göksu Deltası Aşınma Alanlarındaki Kıyı Çizgisi Değişiminin 50 Yı1 Sonraki Konumu 

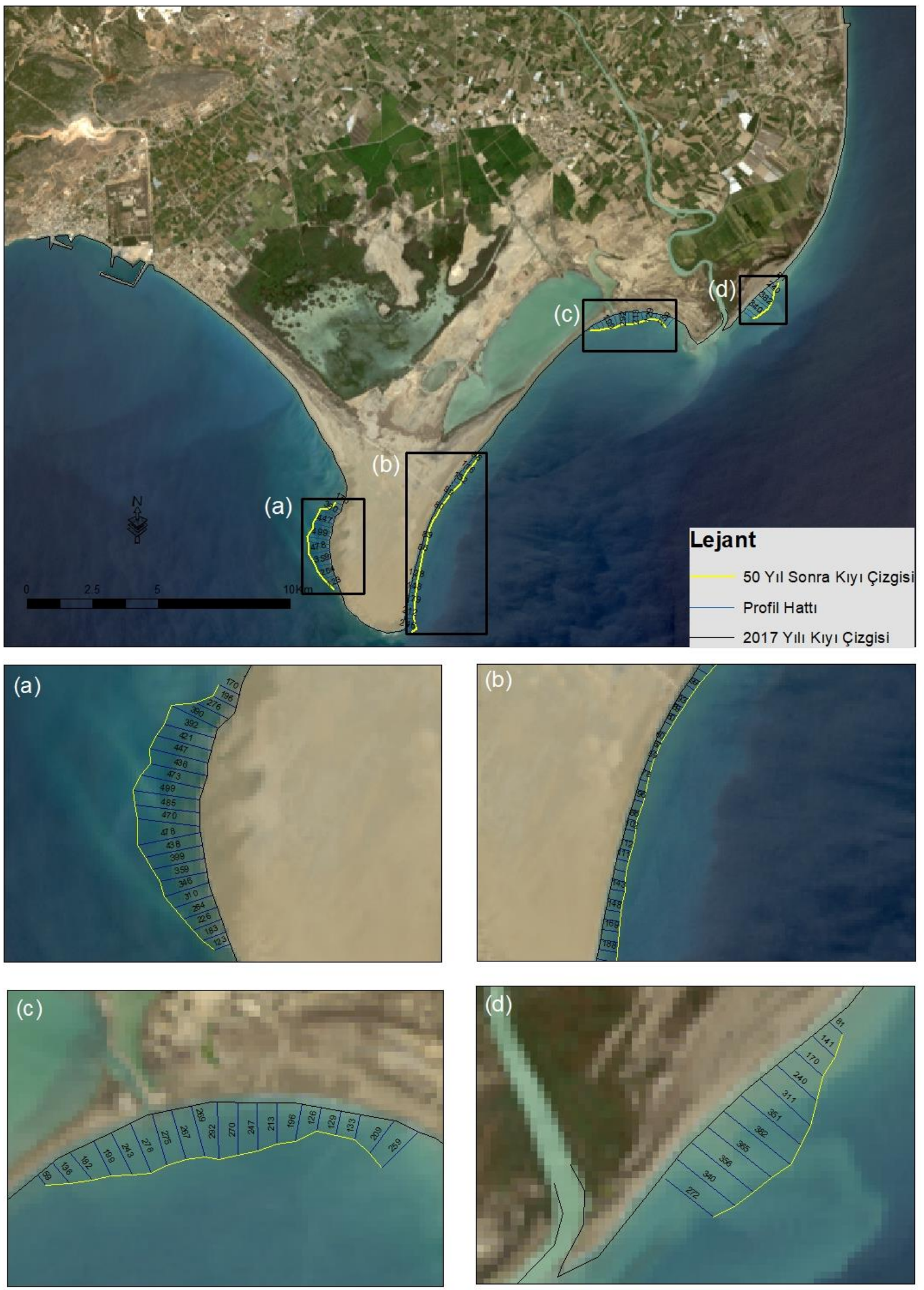

Şekil 10: Göksu Deltası Birikme Alanlarındaki Kıyı Çizgisi Değişiminin 50 Yıl Sonraki Konumu 


\section{Tartışma ve Sonuç}

Göksu deltası kıyı çizgisinin 25 ve 50 yıl sonraki konumlarında meydana gelen değişimler delta kıyılarının morfolojik açıdan önemli ölçüde değişme uğramasına neden olacaktır. Örneğin, Göksu deltasının 25 yıl sonraki kıyı çizgisinin konumunun değerlendirilmesi sonucunda aşınmanın etkili olduğu 97 ha alanın erozyon sonucunda kaybolması beklenirken, birikmenin ekili olduğu 95 ha alanda büyüme ve genişleme meydana gelmesi beklenmektedir (Şekil 11). Bunun yanı sıra, Göksu deltasının 50 yıl sonraki kıyı çizgisinin konumunun değerlendirilmesi sonucunda ise aşınmanın etkili olduğu 196 ha alanda erozyona bağlı küçülme meydana gelmesi beklenirken; birikmenin etkili olduğu 200 ha alanda genişleme ve büyüme meydana gelmesi beklenmektedir (Şekil 12). Sonuç olarak, Göksu deltasının 25 ve 50 yıl sonraki kıyı çizgisinin konumlarında meydana gelen değişimler delta kıyılarının morfolojik yapısında önemli değişimlere neden olacaktır. Göksu deltası kıyı morfolojisinde meydana gelen bu değişimlerden bazıları şunlardır: Paradeniz Lagünü kıyı kordonunun ilerleyen süreçlerde incelerek büyük ölçüde kopması, Altınkum mevkii ile İncekum burnu güneybatı kıyılarında hızlı kıyı çizgisi gerilemesinin meydana gelmesi, delta gelişiminin akarsu ağzı ve çevresi ile İncekum burnun doğu ve batı kıyılarına doğru şekillenmesidir (Şekil 11 ve Şekil 12).

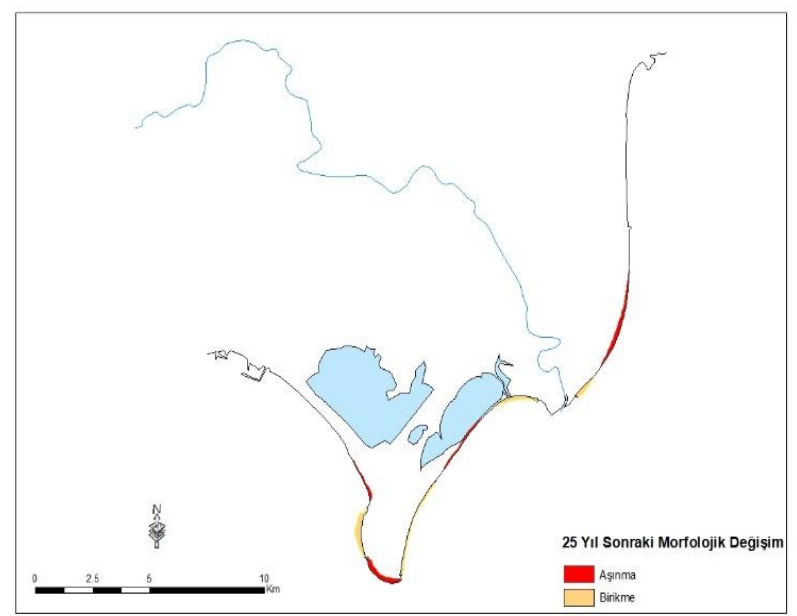

Şekil 11: Göksu Deltası 25 Yı1 Sonraki Kıyı Çizgisi Değişiminin Morfolojik Etkisi

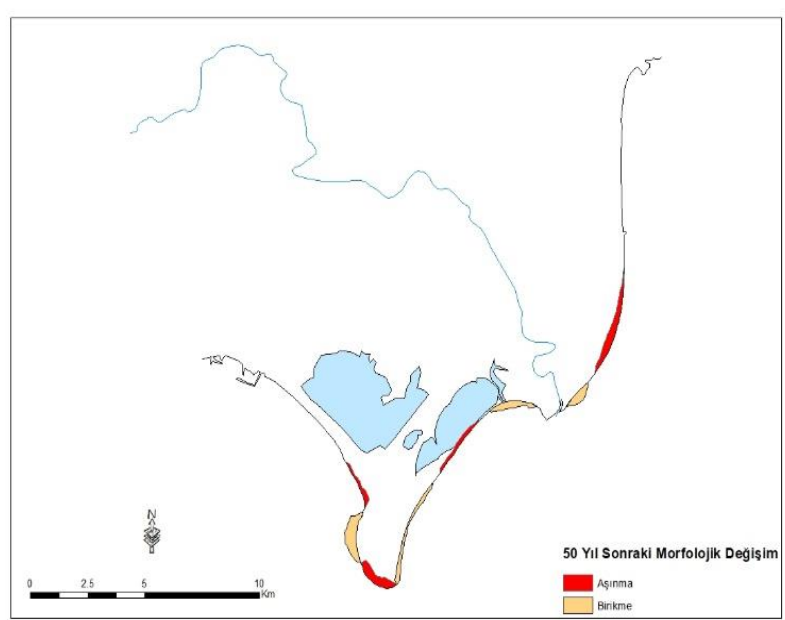

Şekil 12: Göksu Deltası 50 Y1l Sonraki Kıyı Çizgisi Değişiminin Morfolojik Etkisi

Göksu deltasının morfolojik yapısında meydana gelen değişimler delta kıyılarının sosyal, çevresel ve ekonomik kullanımını da önemli ölçüde değiştirmektedir. Göksu deltası kıyı morfolojisinde meydana gelen değişimlerin çevresel koşullar açısından en fazla olumsuz etkilendiği alanlar aşınma faaliyetlerinin yoğun olarak gözlemlendiği alanlardır. Örneğin, Paradeniz lagünü kıyı kordonunun morfolojik acıdan 25 ve 50 yıl sonra önemli ölçüde gerilemesi ve buna bağlı olarak geniş çaplı kopmaların meydana gelmesi daha fazla deniz suyunun lagün içerisinde girmesine neden olacaktır. $\mathrm{Bu}$ durum, Paradeniz Lagününün ve bağlı bulunduğu diğer su kaynaklarının su kalitesinin düşmesine ve lagün ekolojisinin sürdürülebilirliğinin önemli ölçüde azalmasına neden olacaktır. Çalışma sahasında, morfolojik kıyı gerilemelerinin yoğun olarak gözlemlendiği bir diğer alan Altınkum mevkiidir. Altınkum mevkii, Göksu deltasında rekreasyon faaliyetlerinin yoğun olarak gerçekleştirildiği alanlardan biridir. $\mathrm{Bu}$ nedenle, Altınkum mevkiinde meydana gelen morfolojik kıyı gerilemeleri bölgede gerçekleştirilen rekreasyon faaliyetlerinin kalitesini önemli ölçüde düşürmektedir. 
Sonuç olarak, Göksu deltası kıyılarında son yıllarda hızlı kıyı çizgisi değişimleri yaşanmaktadır (Karakoç ve Karabulut, 2010; Kılar ve Çiçek, 2018; Kuleli ve Güneroğlu, 2001). Göksu deltası kıyılarında meydana gelen hızlı kıyı çizgisi değişimleri delta kıyılarının 25 ve 50 yıl sonraki konumlarında önemli değişimlerin meydana gelmesine ve çalışma sahasının morfolojik yapısının değişmesine neden olacaktır. Bilindiği üzere, delta bölgeleri ekolojik acıdan oldukça hassas bir ekosisteme sahiptir. Bu nedenle, Göksu deltası kıyılarında meydana gelen hızlı kıyı çizgisi değişimleri delta kıyılarının ekolojik yapısının değişmesine ve sürdürülebilirliğinin önemli ölçüde azalmasına neden olacaktır. Çalışma sahası kıyılarında meydana gelecek olumsuz koşulların önlenmesi veya en az seviyeye düşürülmesi için kıyı çizgisi değişimleri ile ilgili öngörü çalışmalarının artırması, kıyı çizgisi değişimlerinin belirli aralıklarla belirlenmesi, uzun ve kısa dönemli planlama çalışmalarının hazırlanması oldukça önemlidir.

\section{Teşekkür ve Bilgilendirme}

Bu çalışma Ankara Üniversitesi Bilimsel Araştırma Projeleri (BAP) tarafından yürütülmekte olan "Göksu Deltasında Klyı Çizgisi Değişimlerinin Çok Zamanlı Uydu Görüntüleri ile Analizi”" başlıklı, '15B0759002' kodlu projenin bir bölümünü kapsamaktadır. Desteklerinden dolayı Ankara Üniversitesi BAP birimine teşekkür ederiz. 
To cite: Kılar, H., Çiçek, İ. (2019). The Importance of Determining the Future Position of Shoreline: The Case Study of Göksu Delta, Mersin (Turkey), Coğrafi Bilimler Dergisi/ Turkish Journal of Geographical Sciences, 17(1), 193-216, doi: $10.33688 /$ aucbd.559328

$\begin{array}{ccc}\text { Coğrafi Bilimler Dergisi } & \text { Coğrafi } \\ \text { Bilimler } \\ \text { Dergisi }\end{array}$

\title{
The Importance of Determining the Future Position of Shoreline: The Case Study of Göksu Delta, Mersin (Turkey)
}

\author{
Hatice Kılar*a, İhsan Çiçek ${ }^{b}$
}

\section{EXTENDED ABSTRACT}

\section{Introduction}

Determining the future position of the coastline has a great importance in making effective decisions regarding to the coastal management and also long-term planning of coastal areas (Davidson, et al., 2010: 620; Fenstret, et al., 1993: 147). In order to predict the future position of a shoreline, erosion and accumulation rates of historical shoreline changes have been obtained by converting the linear average into complex morphological effects (Davidson, et al., 2010: 620). For this reason, historical shoreline changes are very important to predict the future shoreline positions (Fenstret, et al., 1993: 147).

Although numerous studies have been carried out on historical shoreline changes, there are not many studies providing predictions about the future position of shoreline changes. While some of these studies focused on developing new methods in predicting the future position of shoreline (Crowel, et al., 1997: 1246; Fenstert, et al., 1993: 149) some of them focused only on the findings in this respect according to study areas (Davidson, et al., 2010: 623; Douglas, et al., 1998: 1027; Douglas and Crowel, 2000: 146).

Coastal areas in delta regions are very fragile to natural disasters due to its low elevation and slope (Kılar and Çiçek, 2017: 3270; K1lar and Çiçek, 2018: 92) and thus, predicting the future shoreline position of delta region is extremely significant in terms of sustainability and long-term planning of coastal areas. In recent years, rapid shoreline changes have occurred in Göksu delta (Gürbüz, 1994: 412; Karakoç and Karabulut, 2010: 197; K1lar and Çiçek, 2018: 102; Kuleli et al., 2011: 1145) and for this reason, this study aims to determine the shoreline position of Göksu delta in 25 and 50 years.

\section{Methodology}

In the study, the Landsat images belonging to 1984 and 2017 on "band ratio" technique of the ENVİ program were used to create a historical shoreline maps of Göksu delta through the DSAS (Digital Shoreline Analysis System) tool of NSM (Net Shoreline Movement) statistic. DSAS is an Arc GIS addin program that enables users to calculate shoreline rate-of-change statistics from multiple historical shoreline positions (Thieler et al., 2009: 4). NSM statistic reports the distance between the oldest and current shorelines for each transect (Kılar and Çiçek, 2018: 95; Thieler et al., 2009: 46). For the historical

\footnotetext{
* Corresponding Author: kilar_hatice@ hotmail.com

a Ankara Üniversity, Department of Geography, Ankara, Türkiye, https://orcid.org/0000-0002-2423-4712

b Ankara Üniversity, Department of Geography, Ankara, Türkiye, https://orcid.org/0000-0002-9000-2805
} 
shoreline change analysis, $\pm 5 \mathrm{~m}$ error ratio was identified as a criteria which is accepted as a suitable value for Landsat images in many studies (Güneroğlu, 2015: 227; Kuleli, 2010: 393). By obtaining the historical shoreline change data, future position of Göksu delta has been predicted.

\section{Result}

\subsection{Historical Shoreline Change}

The results obtained with NSM statistic of historical shoreline changes of 1984 and 2017 showed that the highest shoreline regression occurred in the south eastern part of İncekum with values of 755 and $396 \mathrm{~m}$; meanwhile, the highest shoreline progress was found in the western part of Incekum as well as in the stream mouth was between 277 and $695 \mathrm{~m}$ (Figure 1).

The findings of NSM statistic graph of Göksu delta shoreline changes demonstrated that the highest shoreline progress appeared in the western part of İncekum with an average value of $240 \mathrm{~m}$ between 69 and 89 transects whereas, the highest shoreline regression observed in the southwest coast of Incekum with an average value of $386 \mathrm{~m}$ between 94 and 118 transects (Figure 2) (Kılar and Çiçek, 2018: 98).

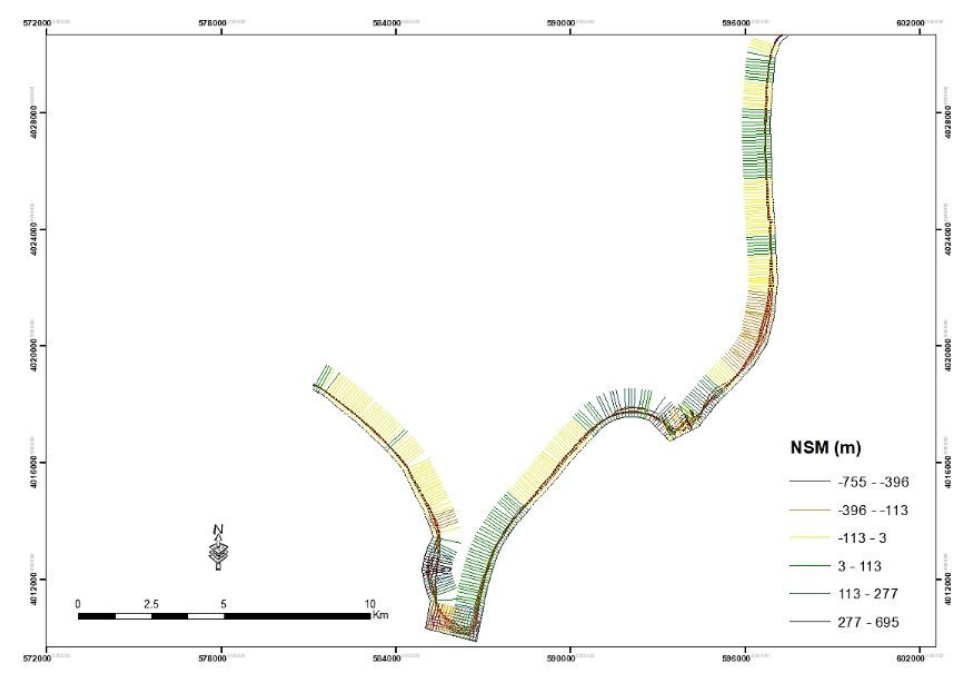

Figure 1: NSM Statistic of Historical Shoreline Changes Reference: Kılar and Çiçek, 2018: 98

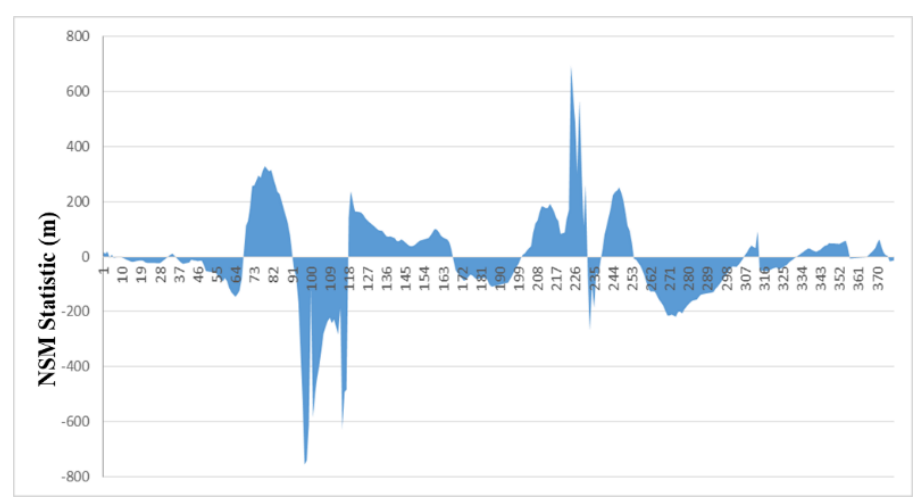

Figure 2: NSM Statistic Graph of Göksu Delta Reference: Kılar and Çiçek, 2018: 99 


\subsection{Future Shoreline Position of Göksu Delta}

\subsubsection{Shoreline Position of Göksu Delta 25 Years Later}

In order to predict the future shoreline of Göksu delta, 25 years later, 193 transects were produced. While 100 of these transects are located in the erosion areas; 93 of them are located in the accumulation areas. As a result of the study, the average shoreline regression rate in the erosion part of study area has been anticipated as $114 \mathrm{~m}$ while the average shoreline progress rate in the accumulation part of study area has been estimated as $119 \mathrm{~m}$ (Figure 3).

\subsubsection{Shoreline Position of Göksu Delta in Erosion Areas 25 Years Later}

The findings indicate that shoreline regression in the erosion areas of Göksu delta will be seen in the western part of İncekum (a), southwestern part of İncekum (b), Paradeniz Lagoon Cord (c) and Altınkum (d) (Figure 4). In addition to that, the average shoreline regression rate is predicted to be 68 $\mathrm{m}$ in the region (a), $218 \mathrm{~m}$ in the region (b), $24 \mathrm{~m}$ in the region (c) and $106 \mathrm{~m}$ in the region (d) (Figure 4).

\subsubsection{Shoreline Position of Göksu Delta in Accumulation Areas 25 Years Later}

As a result of the evaluation of shoreline progress in accumulation areas of Göksu delta, the highest shoreline progress is predicted to take place in the western part of İncekum (a), eastern part of İncekum (b), western part of river mouth (c), and eastern part of river mouth (d). Moreover, the average shoreline progress rate will be $177 \mathrm{~m}$ in the region (a), $57 \mathrm{~m}$ in the region (b), $105 \mathrm{~m}$ in the region(c) and $137 \mathrm{~m}$ in the region (d). Consequently, the highest shoreline progress rate will be observed in the western part of İncekum (a) with the average rate of $177 \mathrm{~m} 25$ years later (Figure 5).

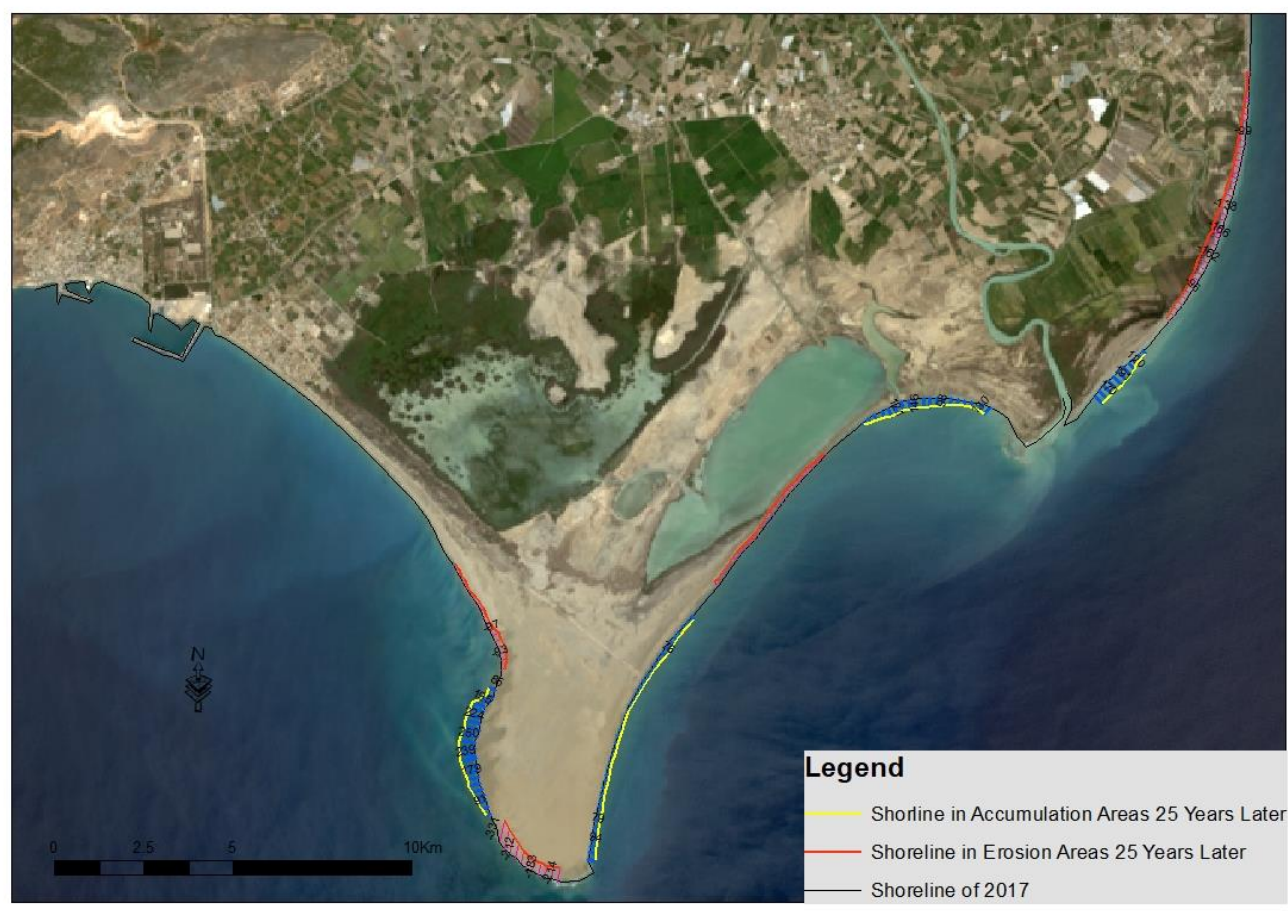

Figure 3: Shoreline Position of Göksu Delta 25 Years Later 

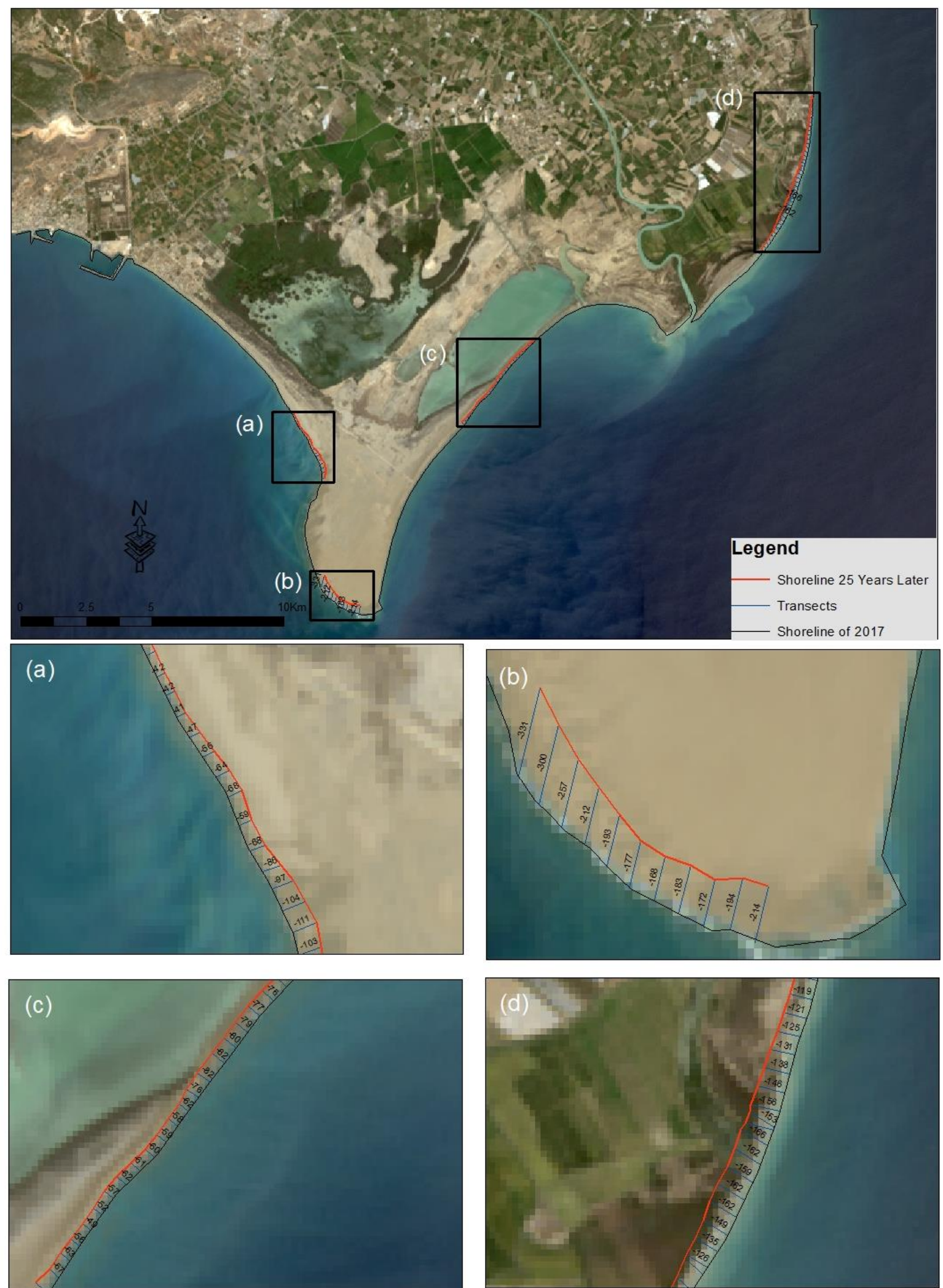

Figure 4: Shoreline Position of Göksu Delta in Erosion Areas 25 Years Later 

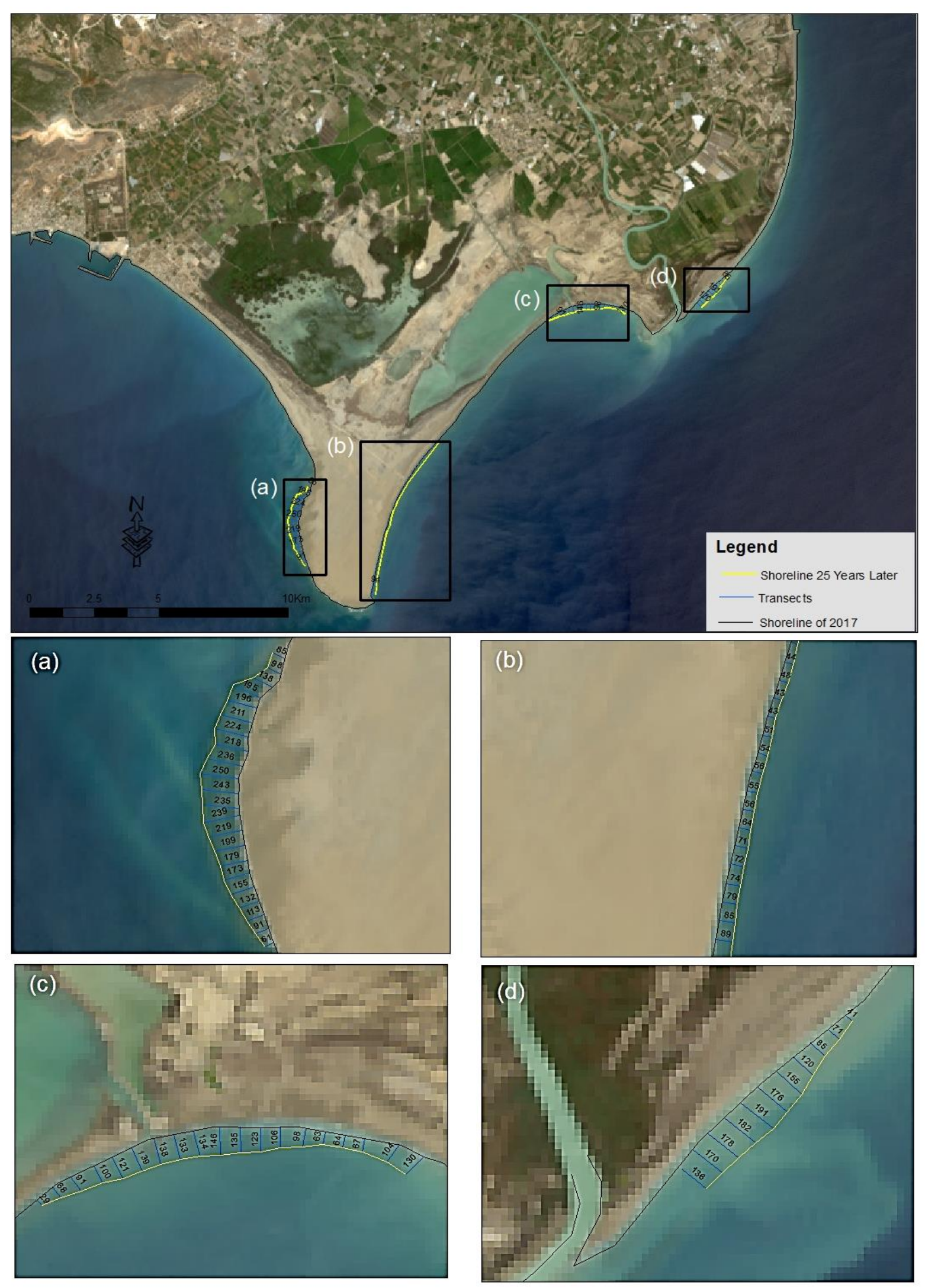

Figure 5: Shoreline Position of Göksu Delta in Accumulation Areas 25 Years Later 


\subsubsection{Shoreline Position of Göksu Delta 50 Years Later}

In order to determine the shoreline position of Göksu delta 50 years later, 202 transects has been produced. While 104 transects were located in the erosion areas of the study area, 98 were located in accumulation areas. By reviewing shoreline position of Göksu delta 50 years later, the average shoreline regression rate in the erosion areas was predicted to be $223 \mathrm{~m}$, while average shoreline progress rate in the accumulation areas was estimated to be $236 \mathrm{~m}$ (Figure 6).

\subsubsection{Shoreline Position of Göksu Delta in Erosion Areas 50 Years Later}

The highest shoreline regression rate in erosion areas of Göksu delta will be observed in the region (a) with an average of $131 \mathrm{~m}$; in the region (b) with an average of $437 \mathrm{~m}$; in the region (c) with an average of $124 \mathrm{~m}$; in the region (d) with an average of $201 \mathrm{~m} 50$ years later. Specifically, the highest shoreline regression rate will occur in the southwestern part of İncekum (b) with an average rate of 437 m (Figure 7).

\subsubsection{Shoreline Position of Göksu Delta in Accumulation Areas 50 Years Later}

The analysis of shoreline progress in accumulation areas of Göksu delta illustrated that the highest shoreline progresses will be identified in the region (a) with an average of $339 \mathrm{~m}$; in the region (b) with an average of $121 \mathrm{~m}$; in the region (c) with an average of $210 \mathrm{~m}$; in the region (d) with an average of $274 \mathrm{~m}$. In depth, the highest shoreline progress rate will be observed in the western part of İncekum (a) with the average rate of $339 \mathrm{~m}$ (Figure 8).

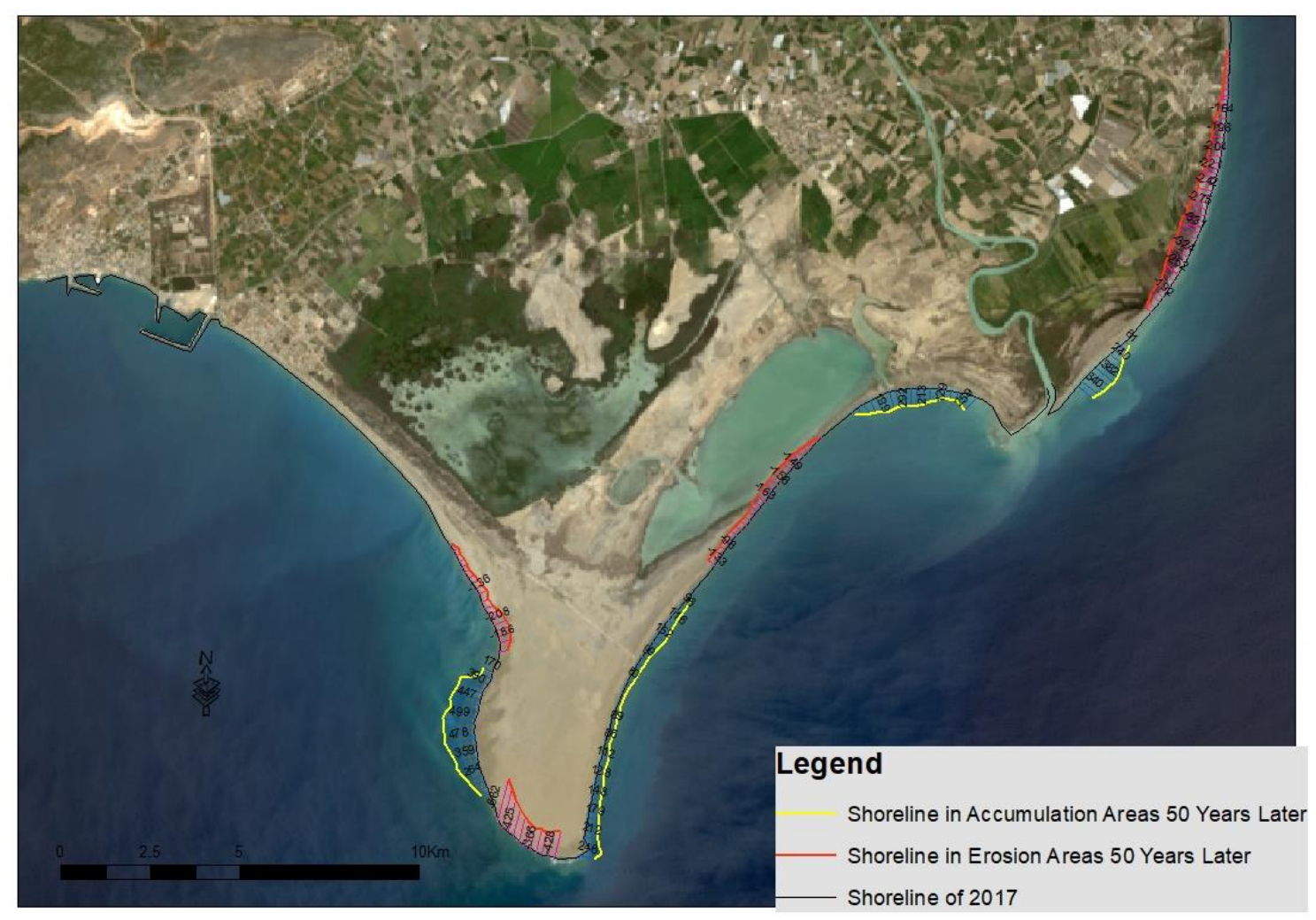

Figure 6: Shoreline Position of Göksu Delta 50 Years Later 

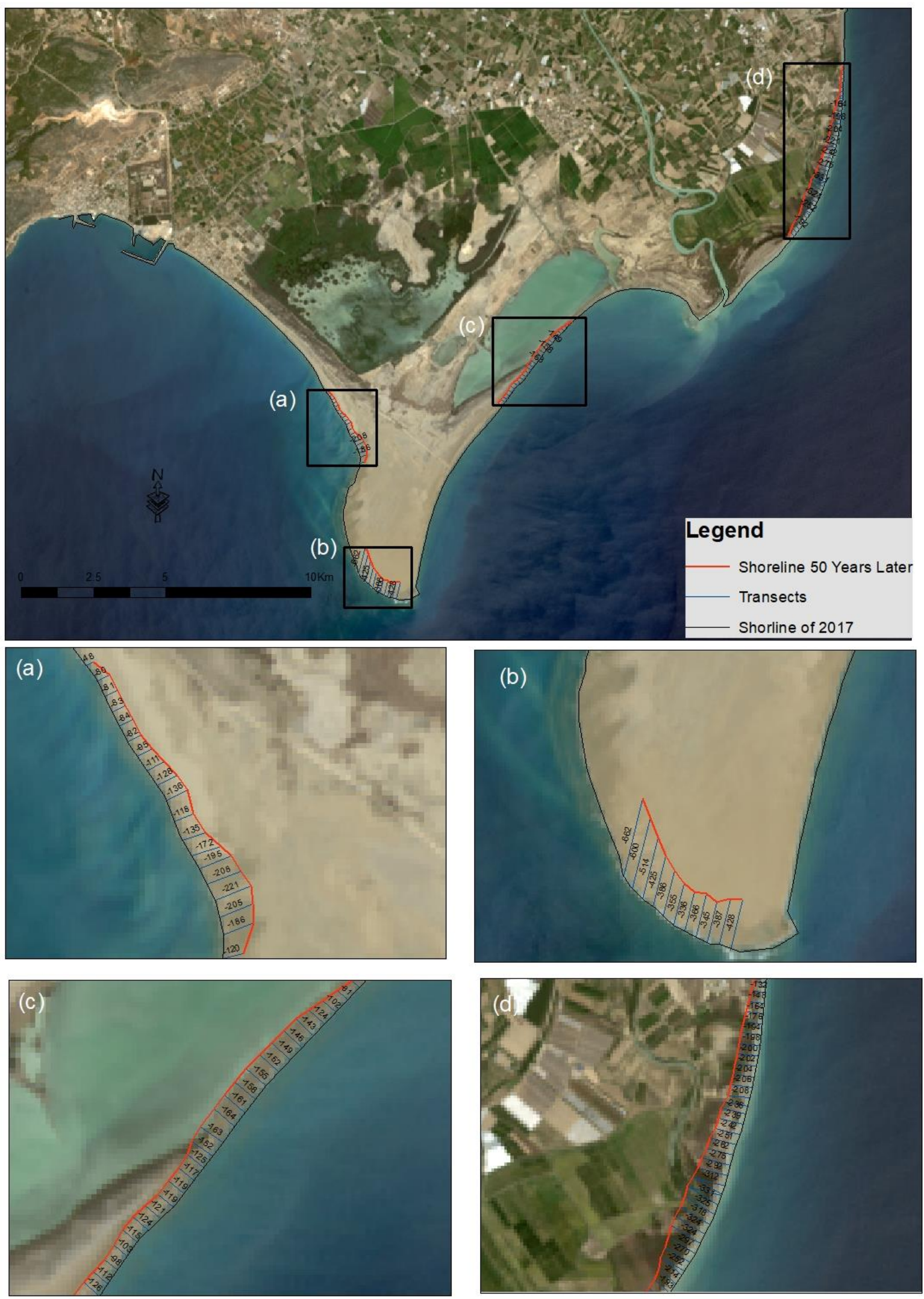

Figure 7: Shoreline Position of Göksu Delta in Erosion Areas 50 Years Later 

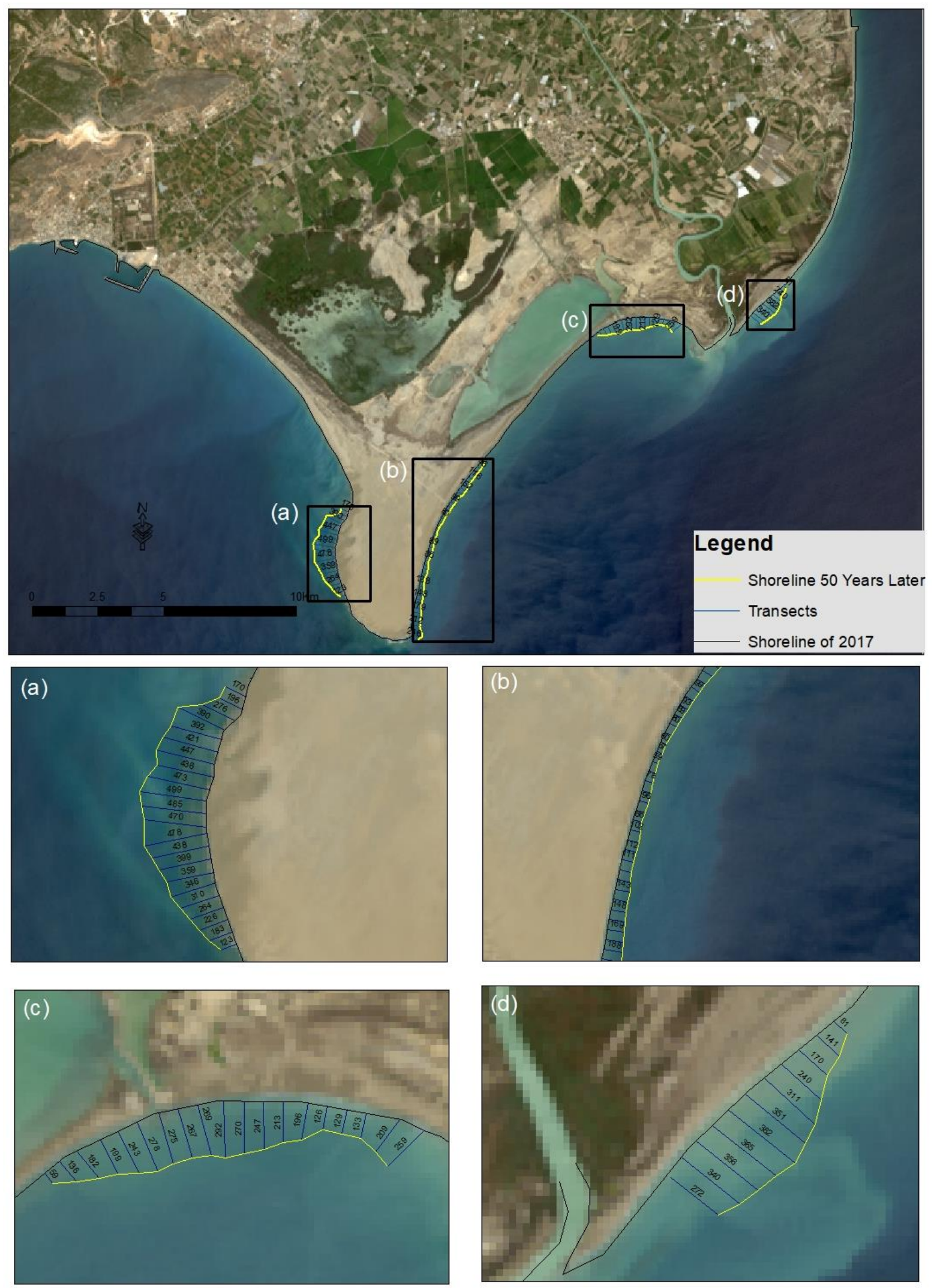

Figure 8: Shoreline Position of Göksu Delta in Accumulation Areas 50 Years Later 


\section{Conclusions and Discussion}

Through analysis of the future shoreline position of Göksu delta, it was defined that significant changes will be observed especially in the morphology of the study area. On evaluation of the location of the shoreline 25 years later, it has been predicted that 97 hectares of coastal land will be lost due to intensive erosion and 95 hectares of coastal land will be gained due to accumulation activities. Furthermore, when shoreline position of Göksu delta 50 years later was assessed, it was determined that 196 hectares of coastal land will be eroded and 200 hectares of coastal land will be accumulated. Hereby, the future shoreline changes of Göksu delta will cause significant morphological changes through degradation and expansion of coastal areas owing to intensive erosional and sedimentation activities. As Paradeniz Lagoon, the southwest coast of Incekum and Altınkum are important areas that might be exposed to shoreline regression in the erosion part of Göksu delta, western part of İncekum, western and eastern part of Göksu river mouth are the other areas where shoreline progress might be seen (Figure 9, $10)$.

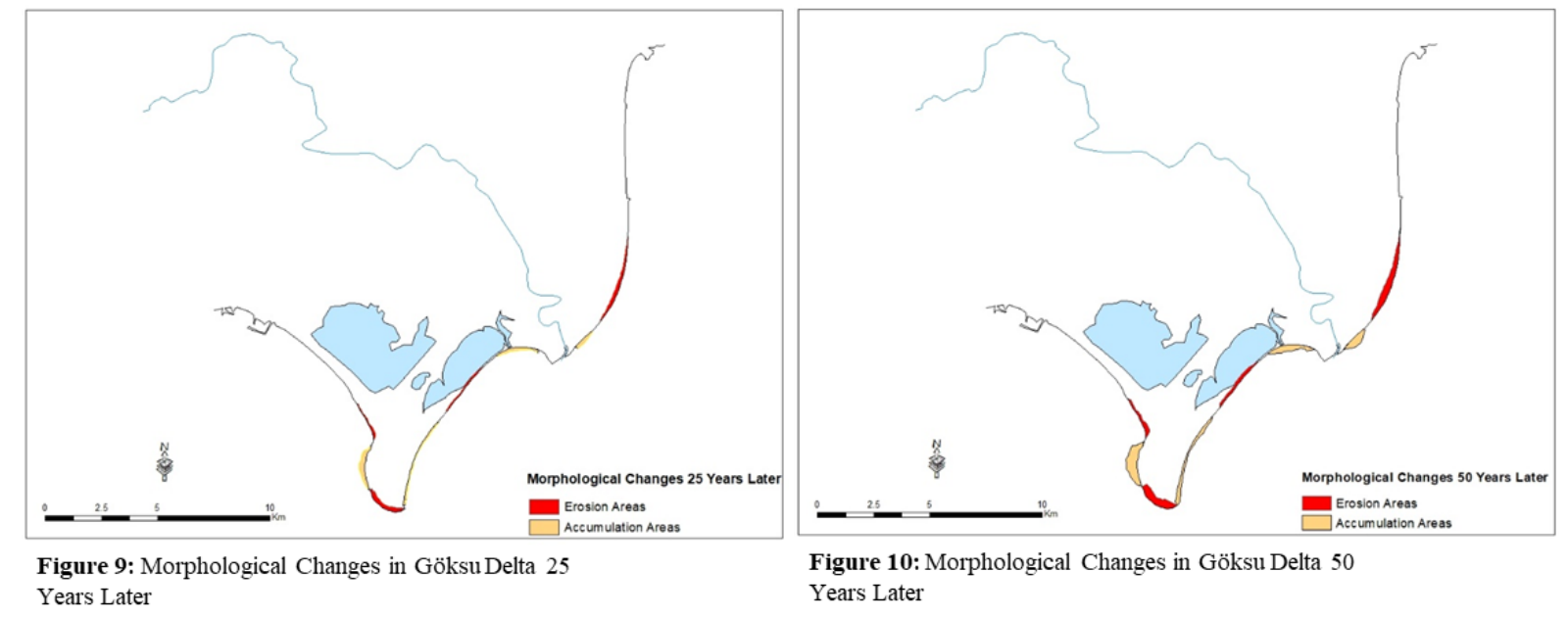

On basis of the future shoreline changes, it was inferred that these changes will affect social, environmental and economic coastal land use of the study area. One of the most crucial environmental impacts might take place in Paradeniz Lagoon. As it is known, Paradeniz Lagoon has a very rich ecosystem. Thus, ecological balance of the lagoon is very sensitive. As a result, the environmental changes in the lagoon will decrease the sustainability of the ecosystem. As mentioned above, the cord of the Paradeniz Lagoon will probably be eroded significantly in 25 and 50 years later. This severe erosion will lead to more see water entrance to the lagoon. This will increase the salinity level of the Paradeniz Lagoon and change its natural ecosystem. On the other hand, when the economic effects of the coastal morphological changes were taken into account, Altınkum will be the most influenced district since it is one of the most popular regression areas in the Göksu delta. Due to this, any negative impacts on the recreational activities of Altınkum will decrease the economic sustainability of the region.

\section{Referanslar/ References}

Crowel, M., Douglas B.C., Leatherman, S.P. (1997). On Forecasting Future U.S. Shoreline Positions: A Test of Algorithms, Journal of Coastal Research, 13 (4), 1245-1255.

Davidson, M.A., Lewis, R.P., Turner, I.L. (2010). Forecasting Seasonal to Multi-Year Shoreline Change, Coastal Engineering, 57, 620-629. doi: 10.1016/j.coastaleng.2010.02.001

Douglas, B.C., Crowel, M., Leatherman, S.P. (1998). Considerations for Shoreline Position Prediction, Journal of Coastal 
Research, 14 (3), 1025-1033.

Douglas B.C., Crowel, M. (2000). Long-term Shoreline Position Prediction and Error Propagation, Journal of Coastal Research, $16(1), 145-152$.

Fenstert, M.S., Dolant, R., Elder, J.F. (1993). A New Method for Predicting Shoreline Position Historical Data, Journal of Coastal Research, 9 (1), 147-171.

Gedik, A., Birgili, S., Yılmaz, H., Yoldaş, R. (1979). Mut-Ermenek-Silifke Yöresinin Jeolojisi ve Petrol Olanakları, Türkiye Jeol. Kur. Bült. 22, 7-26.

Gökten, E. (1976). Silifke Yöresinin Temel Kaya Birimleri ve Miyosen Stratigrafisi. Türkiye Jeol. Kur. Bült.19, 117-126.

Gülkal, O. (1992). Göksu Deltası'nın Doğal ve Kültürel Potansiyelinin Belirlenmesi ve Kullanımlar Yönünden Değerlendirilmesi. Çukurova Üniversitesi, Fen Bilimleri Enstitüsü, Basılmamış Yüksek Lisans tezi, Adana-Türkiye.

Güneroğlu, A. (2015). Coastal Changes and Land Use Alteration on Northeastern Part of Turkey, Ocean \& Coastal Management, 118, 225-233. doi: 10.1016/j.ocecoaman.2015.06.019

Gürbüz, O. (1994). Göksu Deltası'nın Doğu Kıyısında Kıyı Çizgisi Gerilemesi ve Sonuçları, Türk Coğrafya Dergisi, $29,409-417$.

Karakoç, A., Karabulut, M. (2010). Göksu Deltası Kıyı Çizgisinde Meydana Gelen Değişimlerin CBS ve Uzaktan Algılama Teknikleri ile İncelenmesi. Ulusal Jeomorfoloji Sempozyumu, Afyon.

Keçer, M. (2001). Göksu Deltası'nın (Mersin) Jeomorfolojik Evrimi ve Güncel Akarsu-Deniz-Rüzgar Süreçlerinin Kıyı Çizgisinde Yaptı̆̆ Değişiklikler. Yayınlamamış MTA Raporu No: 10468.

Keçer M., Duman, T. Y. (2007). Yapay Etkilerin Göksu Deltası Gelişimine Etkisi, Mersin-Türkiye, MTA Dergisi, 26, 134-17.

Kılar H., Çiçek İ. (2017). Göksu Deltası'nda Fırtına Kabarmasına Bağlı Deniz Seviyesi Değişimleri, International Journal of Human Sciences, 14 (4), 3268-3281. doi:10.14687/jhs.v14i4.4739.

Kılar H., Çiçek İ. (2018). Göksu Deltası Kıyı Çizgisi Değişiminin DSAS Aracı ile Belirlenmesi, Coğrafi Bilimler Dergisi, 16 (1), 89-104. doi: 10.1501/Cogbil_0000000192.

Kuleli, T. (2010). Quantitative Analysis of Shoreline Changes at the Mediterranean Coast in Turkey, Environ Monit Assess, 167 , 387-397. doi: 10.1007/s10661-009-1057-8.

Kuleli, T., Güneroğlu, A., Karslı, F., Dihkan, M. (2011). Automatic Detection of Shoreline Change on Coastal Ramsar Wetlands of Turkey, Coastal Engineering, 38, 1141-1149. doi: 10.1016/j.oceaneng.2011.05.006.

Meriç S., Kavruk, S. (2007). Göksu Deltası Kıyı Yönetiminin Dünü ve Bugünü. TMMOB İşaat Mühendisleri 6. Ulusal Kıyı Mühendisliği Sempozyumu, 25-28 Ekim 2007, İzmir.

Thieler, E. R., Himmelstoss, E. A., Zichichi, J. L., Ergul, A. (2009). The Digital Shoreline Analysis System (DSAS) Version 4.0 An ArcGIS Extension for Calculating Shoreline Change. Open-File Report. US Geological Survey Report No. 20081278. http://woodshole.er.usgs.gov/projectpages/dsas/version4/

Uslu, T. (1993). Göksu Delta'sında Kıyı Kumul Yönetimi. Uluslararası Göksu Delta'sı Çevresel Kalkınma Semineri, Doğal Hayatı Koruma Cemiyeti-İstanbul. 